Article

\title{
The Use of Platelet-Rich Plasma to Promote Cell Recruitment into Low-Molecular-Weight Fucoidan-Functionalized Poly(Ester-Urea-Urethane) Scaffolds for Soft-Tissue Engineering
}

\author{
Géraldine Rohman ${ }^{1, *}\left(\mathbb{0}\right.$, Credson Langueh ${ }^{1}$, Salah Ramtani ${ }^{2}{ }^{\circledR}$, Jean-Jacques Lataillade ${ }^{3}$, \\ Didier Lutomski ${ }^{1}$, Karim Senni ${ }^{4}$ and Sylvie Changotade ${ }^{1}$ \\ 1 Tissue Engineering and Proteomics (TIP) team, CSPBAT UMR CNRS 7244, Université Paris 13, \\ Sorbonne Paris Cité, 74 rue Marcel Cachin, 93000 Bobigny, France; credsonlangueh@gmail.com (C.L.); \\ lutomski@univ-paris13.fr (D.L.); changotade@univ-paris13.fr (S.C.) \\ 2 LBPS team, CSPBAT UMR CNRS 7244, Université Paris 13, Sorbonne Paris Cité, \\ 99 avenue Jean-Baptiste Clément, 93430 Villetaneuse, France; ramtani@univ-paris13.fr \\ 3 Institut de Recherche Biomédicale des Armées, Unité de Thérapie Cellulaire et Réparation Tissulaire, \\ Site du Centre de Transfusion Sanguine des Armées "Jean Julliard" de Clamart, BP 73, \\ 91223 Brétigny-sur-Orge Cedex, France; jjlataillade@gmail.com \\ 4 Ecole de biologie Industrielle, 49 avenue des Genottes, 95885 Cergy Cedex, France; senni_k@yahoo.com \\ * Correspondence: geraldine.rohman@univ-paris13.fr; Tel.: +33-1-4838-8883
}

Received: 24 March 2019; Accepted: 7 June 2019; Published: 9 June 2019

\begin{abstract}
Due to their elastomeric behavior, polyurethane-based scaffolds can find various applications in soft-tissue engineering. However, their relatively inert surface has to be modified in order to improve cell colonization and control cell fate. The present study focuses on porous biodegradable scaffolds based on poly(ester-urea-urethane), functionalized concomitantly to the scaffold elaboration with low-molecular-weight (LMW) fucoidan; and their bio-activation with platelet rich plasma (PRP) formulations with the aim to promote cell response. The LMW fucoidan-functionalization was obtained in a very homogeneous way, and was stable after the scaffold sterilization and incubation in phosphate-buffered saline. Biomolecules from PRP readily penetrated into the functionalized scaffold, leading to a biological frame on the pore walls. Preliminary in vitro assays were assessed to demonstrate the improvement of scaffold behavior towards cell response. The scaffold bio-activation drastically improved cell migration. Moreover, cells interacted with all pore sides into the bio-activated scaffold forming cell bridges across pores. Our work brought out an easy and versatile way of developing functionalized and bio-activated elastomeric poly(ester-urea-urethane) scaffolds with a better cell response.
\end{abstract}

Keywords: fucoidan; PRP; poly(ester-urea-urethane); scaffold; tissue engineering

\section{Introduction}

Tissue engineering is a multi-step and multi-component approach, aiming to combine a porous and biodegradable polymeric structure with bioactive factors in order to elaborate appropriate scaffolds conducive to cell adhesion, proliferation and function maintenance, as well as vascularization and tissue regeneration [1]. As a consequence, compelling requirements have been identified for scaffold design: (1) Being easily shaped for large-scale manufacturing through a simple and controlled process, and allowing material morphologies that can fit in the defect geometry in order to correctly define and maintain the space for tissue regeneration; (2) possessing a multi-scale interconnected porous structure, 
enabling cell migration, provision of oxygen and nutrients to engineered tissue prior to vascularization, as well as the evacuation of metabolic waste; (3) surface properties that could support and enhance the delivery of bio-factors in order to stimulate cell proliferation, cell differentiation, matrix remodeling and angiogenesis. One target of tissue engineering is to ensure an effective colonization of scaffolds by cells, which can lead subsequently to tissue development. As a consequence, classical tissue engineering approaches rely on the seeding of cells onto the scaffold to potentiate the biomaterial regenerative properties. However, the seeding-time, the cost, the heterogeneity of the scaffold colonization, a loss of cell viability and proliferation are critical obstacles [2]. In contrast, cell-free based-tissue engineering is a straightforward approach leaning on inductive scaffolds capable of recruiting resident cells and guiding them to form a functional structure. Rapid cell infiltration, migration and proliferation into the porous biomaterial are of high importance for tissue regeneration, and may be enhanced by the delivery of biological cues from optimized scaffolds.

Various scaffolds, based on natural, synthetic and composite materials, have been proposed for tissue engineering and are described in the literature. In the field of soft-tissue engineering, the choice of the material used for the scaffolding matrix is limited by their mechanical stiffness, since most non-mineralized tissues to replace exhibit elastic moduli ranging from 0.01 to $1000 \mathrm{kPa}$ [3]. As a consequence, elastomeric polyurethane-based scaffolds have found various applications in soft-tissue engineering, due to their good biocompatibility, rubber-like elasticity, high fatigue resistance, easiness of elaboration into different morphologies, and their versatility in terms of tailoring degradation rates $[4,5]$. However, polyurethane-based scaffolds exhibit an inert surface that has to be modified in order to improve cell colonization and to control cell fate. Therefore, a variety of approaches have been proposed in the literature to incorporate functional groups or immobilize biomolecules $[5,6]$. To improve scaffold efficiency and provide biological cues that promote tissue regeneration, it has been shown that the addition of growth factors presents great advantages [7]. Lately, platelet rich plasma (PRP) has been increasingly used in various tissue regeneration applications, since PRP contains more than 300 biologically-active molecules, with a high levels of growth factors, including the transforming growth factor $\beta$ (TGF- $\beta$ ), insulin-like growth factor 1 (IGF-1), platelet-derived growth factor (PDGF), fibroblast growth factor (FGF). PRP also contains adhesion molecules, and is a vast reservoir of proteins [8-10]. PRP has been widely used as a therapeutic tool in the orthopedic field, because it allows the delivery of osteogenic and angiogenic factors [11,12]. The effect of PRP on various cell types has been studied in vitro, and PRP demonstrates adhesive, proliferative, differentiative and chemo-attractive properties $[10,13,14]$. For instance, PRP can stimulate dermal fibroblast migration and proliferation, showing its potential in wound treatment and skin rejuvenation [15]. Therefore, the incorporation of PRP in scaffolds is an advantageous approach, because it represents a simple, efficient and cost-effective method, allowing the immobilization of a number of highly-concentrated bioactive factors, creating an optimized micro-environment, and impacting upon tissue regeneration [10,16-19]. Various approaches have been developed to immobilize growth factors inside the scaffolds, and these may be envisioned for immobilizing PRP, such as physical encapsulation, absorption onto the biomaterial surface, layer-by-layer self-assembly, covalent conjunctions and extracellular matrix-based binding approaches [20]. In the latter bioaffinity-tethering approaches via charge interactions, sulfated glycosaminoglycans, such as heparin, have been widely used to design scaffolds with a highly spatio-temporal delivery capacity [21,22]. However, both polysaccharide extraction from animal tissue and chemical synthesis can be difficult, and can lead to macromolecules with various purity, structures, sulfation degrees and molecular weight dispersity. As a consequence, heparin-mimicking polymers which have been more structurally defined offer great advantages. In turn, the use of non-animal sulfated polysaccharides, such as fucoidans from brown seaweed, could be a clever approach. Attempts to immobilize fucoidan within polysaccharide scaffolds demonstrated that the content of fucoidan increased with its molecular weight. However, better growth factor retention was found for molecular weights in the range $20-40 \mathrm{kDa}[23,24]$. Indeed, low-molecular-weight (LMW) fucoidans are largely described as heparin mimetic, since they are able to protect and promote a number 
of growth factors, such as FGF-2 and vascular endothelial growth factor (VEGF), and to regulate tissue homeostasis [25-30].

LMW fucoidans have been investigated in therapeutic applications when used in soluble forms, as well as in medicine applications as a part of drug carriers, imaging agents, nano-systems for diagnostic and biomaterials for tissue regeneration [31,32]. Despite their bioactive properties, LMW fucoidans remain relatively unexploited, and very few studies reported their use to functionalize polymeric scaffolds.

Porous biodegradable scaffolds based on poly(ester-urea-urethane) (PEUU) were developed in our laboratory with various multi-scale and interconnected porosities. The scaffolds were appropriate for cell adhesion, allowed cell spreading over the pore walls, as well as a proliferation and osteogenic differentiation of stem cells seeded onto the scaffold $[33,34]$. Preliminary in vivo experiments dedicated to bone regeneration demonstrated the biocompatibility and the osteoconductive and osteoinductive properties of the PEUU scaffolds. Indeed, PEEU scaffolds were capable of recruiting resident osteoblastic progenitor cells, guiding cell migration and proliferation into the scaffold and inducing cell differentiation into mature osteoblasts [34]. With the aim of developing scaffolds for cell-free based-soft tissue engineering that can allow cell recruitment and scaffold colonization, keeping in mind that cell infiltration, migration, proliferation, as well as collagenous matrix making must be enhanced, the present study focuses on the PEUU scaffold bio-activation through a convenient surface modification, that can provide an appropriate surface chemistry for growth factors retention and extracellular matrix deposit. Herein, low-molecular-weight fucoidan functionalized-poly(ester-urea-urethane) scaffolds (PEUUF) were synthesized by incorporating LMW fucoidan concomitantly with the scaffold elaboration. Thereafter, PEUUF scaffolds were bio-activated through the adsorption of platelet rich plasma (PRP) formulations. Finally, preliminary in vitro assays were assessed to demonstrate the improvement of the scaffold behavior towards fibroblast response.

\section{Materials and Methods}

\subsection{Materials}

All solvents were purchased from Fisher, and were used as received. Phosphate buffered saline solution (PBS), Dulbecco's modified Eagle's medium (DMEM), fungizone antimycotic (Fz), penicillin (Pen), streptomycin (Strep) and trypsin-EDTA were supplied by Gibco Life Technologies (Dún Laoghaire, Ireland). Triol poly( $\varepsilon$-caprolactone) oligomers, hexamethylene diisocyanate (HMDI), Span ${ }^{\circledR} 80$, dibutyltin dilaurate (DBTDL), collagenase, paraformaldehyde (PFA), sodium chloride $(\mathrm{NaCl})$, hydrochloric acid $(\mathrm{HCl})$, picric acid, Sirius red, toluidine blue and hematein were purchased from Sigma-Aldrich, and Coomassie blue from BIO-RAD (Hercules, CA, USA). Low-molecular-weight (LMW) fucoidan (16-20 kDa, $40 \mathrm{wt} \%$ sulfate) was provided by the Solabia Group (Pantin, France). Fetal bovine serum (FBS) was obtained from PANBiotech GmbH (Aidenbach, Germany).

Heparin and clinical platelet rich plasma (PRP) formulations were supplied by the Centre de Transfusion Sanguine des Armées (CTSA) “Jean Julliard”- - Hôpital d'Instruction des Armées Percy (Clamart, France). PRP was collected from platelet donations from healthy patients. Clinical PRP formulations were prepared from pools of platelets obtained from the CTSA Blood Bank.

Human dermal fibroblasts were isolated, using standard procedures, from the foreskins of 4-year-old children with the informed consent of their parents. Fibroblasts were used for the experiments at passage 7. The study was conducted in accordance with the Declaration of Helsinki and applicable local regulatory requirements and laws, that is to say the article L.1243-4 of the French Public Health Code. Given its special nature, surgical residue is subject to specific legislation included in the French Code of Public Health (anonymity, gratuity, sanitary/safety rules). This legislation does not require prior authorization by an ethics committee for any sampling or the use of surgical waste. 


\subsection{Elaboration of PEUUF Scaffolds}

PEUUF scaffolds were obtained through the use of the high internal phase emulsion (HIPE) process by incorporating LMW fucoidan into the same high internal phase emulsion (HIPE) aqueous phase. An example of the preparation of a PEUUF scaffold is given hereafter. LMW fucoidan $(0.34 \mathrm{~g})$ was dissolved in $34 \mathrm{~mL}$ of sterile distilled water $(0.2 \mu \mathrm{m}$ filtered). Triol poly( $\varepsilon$-caprolactone) oligomers $(1.3 \mathrm{~g})$ and $\operatorname{Span}^{\circledR} 80(1.3 \mathrm{~g})$ were placed in a reactor and dissolved in toluene $(4.8 \mathrm{~mL})$. Thereafter, the cross-linking agent HMDI $(1.04 \mathrm{~mL})$ and DBTDL catalyst $(600 \mu \mathrm{L})$ were added under stirring using a mechanical stirrer. Finally, the aqueous fucoidan solution $\left(C=10 \mathrm{mg} \mathrm{mL}^{-1}\right)$ was slowly introduced under stirring, leading to a stable paste-like emulsion. The HIPE was transferred in a mold and heated in an oven at $55^{\circ} \mathrm{C}$ for $22 \mathrm{~h}$ followed by $2 \mathrm{~h}$ at $90^{\circ} \mathrm{C}$. Subsequently, the material was unmolded, and water and the excess of solvent were removed by squeezing. After 3 days of air-drying, the scaffold was cut into discs with a thickness of $2 \mathrm{~mm}$ and washed 2 times in dichloromethane for $24 \mathrm{~h}$, then $24 \mathrm{~h}$ in dichloromethane/hexane 50/50 vol\%, followed by $24 \mathrm{~h}$ in hexane and finally 2 times in distilled water for $24 \mathrm{~h}$.

\subsection{Bio-Activation of PEUUF Scaffolds with PRP Formulations}

First, PEUUF scaffolds were immersed in sterile water for $1 \mathrm{~h}$ under a vacuum system, followed by a $4 \mathrm{~h}$ immersion after a water change. Thereafter, scaffolds were immersed for $1 \mathrm{~h}$ in $70 \mathrm{vol} \%$ ethanol under a vacuum system. Finally, scaffolds were rinsed in sterile water overnight and autoclaved in a wet condition. After sterilization, scaffolds were incubated at $37^{\circ} \mathrm{C}$ in a humidified atmosphere of $5 \%$ $\mathrm{CO}_{2}$ in DMEM/Pen $\left(100 \mathrm{IU} \cdot \mathrm{mL}^{-1}\right) / \mathrm{Strep}\left(100 \mu \mathrm{g} \cdot \mathrm{mL}^{-1}\right) / \mathrm{Fz}\left(2.5 \mu \mathrm{g} \cdot \mathrm{mL}^{-1}\right)$ for $12 \mathrm{~h}$, and thereafter $16 \mathrm{~h}$ in DMEM/Pen (100 IU.mL $\left.{ }^{-1}\right) /$ Strep $\left(100 \mu \mathrm{g} \cdot \mathrm{mL}^{-1}\right)$ supplemented with PRP (15 vol\%). Finally, scaffolds were rinsed once in PBS.

\subsection{Scaffold Characterization}

Scaffolds were characterized by the determination of their density, porosity and pore interconnectivity (volumetric adsorption ratio), as previously described [33]. The scaffold morphology was monitored using an environmental scanning electron microscope (ESEM TM3000 - Hitachi, Tokyo, Japan), operating at an accelerated voltage of $15 \mathrm{kV}$, and a digital microscope Keyence VHX-5000 (Osaka, Japan). The scaffold chemical composition was monitored by Fourier-transformed infrared spectroscopy (FTIR Nicolet 380-Thermo Fisher Scientific, Waltham, MA, USA) in an attenuated total reflectance mode (ATR-Smart Omni Sampler, Thermo Fisher Scientific, Waltham, MA, USA) within the range $700-4000 \mathrm{~cm}^{-1}$ with a resolution of $4 \mathrm{~cm}^{-1}$. The scaffold effective modulus of elasticity $\mathrm{E}_{1}$ * was determined during compression in the axial direction to the foam rise with a $500 \mathrm{~N}$ force range, $7 \mathrm{~mm}$ displacement range and $5 \mathrm{~mm} \mathrm{~min}^{-1}$ testing speed, as previously described [35]. The scaffold number average molecular weight between cross-links $\overline{\mathrm{M}}_{\mathrm{c}}$ was determined through the swelling measurements in toluene up to the swelling equilibrium, as previously described [35]. The scaffold hydrophilicity/hydrophobicity was determined through the water contact angle measurements using a Digidrop Model DS GBX apparatus (GBX Scientific, Tallaght, Ireland) and Windrop++ software, and through the water uptake. The scaffolds were weighed before water immersion $\left(\mathrm{W}_{\mathrm{dry}}\right)$ and after removing from distilled water $\left(\mathrm{W}_{\text {wet }}\right)$. The water uptake was calculated using Equation (1):

$$
\text { Water Uptake }=\left(\mathrm{W}_{\text {wet }}-\mathrm{W}_{\text {dry }}\right) \times 100 / \mathrm{W}_{\text {dry }}
$$

The evidence of scaffold functionalization by LMW fucoidan was monitored by Fourier-transformed infrared (FTIR)-attenuated total reflection (ATR) spectroscopy, and the amount of fucoidan immobilized inside the scaffold was determined using a toluidine blue assay [36]. Ground scaffolds were immersed for $1 \mathrm{~h}$ in $2 \mathrm{~mL}$ of $\mathrm{H}_{2} \mathrm{O} / 0.2 \mathrm{wt} \% \mathrm{NaCl}$ solution and $1 \mathrm{~mL}$ of toluidine blue solution $\left(\mathrm{C}=0.062 \mathrm{mg} \cdot \mathrm{mL}^{-1}\right.$ in $\left.0.01 \mathrm{M} \mathrm{HCl} / 0.2 \mathrm{wt} \% \mathrm{NaCl}\right)$. Thereafter, $3 \mathrm{~mL}$ of hexane were added to the mixture and it was shaken well. The aqueous layer was then extracted and the absorbance measured at 
$632 \mathrm{~nm}$ with a UV-visible spectrophotometer (UVM 340 spectrophotometer, Mettler Toledo, Columbus, $\mathrm{OH}, \mathrm{USA})$.

A linear relationship between the absorbance of residual toluidine blue in the aqueous phase and the concentration of fucoidan in aqueous solution was obtained from a calibration curve and used to determine the amount of fucoidan immobilized inside the scaffold.

The evidence of PRP immobilization was monitored by FTIR-ATR spectroscopy and by imaging the scaffold stained by Coomassie blue with a digital microscope Keyence VHX-5000. The amount of PRP immobilized inside the scaffold was determined using a 2D Quant kit (GE Healthcare, Chicago, IL, USA).

\subsection{Evaluation of Scaffold Stability}

The scaffold stability was assessed through degradation tests in accordance with ISO 10993-13 guidelines. After sterilization by autoclaving, $0.1 \mathrm{~g}$ of PEUUF scaffolds were immersed in $1 \mathrm{~mL}$ of degradation medium composed of DMEM/Pen $\left(100 \mathrm{IU} \cdot \mathrm{mL}^{-1}\right) /$ Strep $\left(100 \mu \mathrm{g} . \mathrm{mL}^{-1}\right) / \mathrm{Fz}\left(2.5 \mu \mathrm{g} \cdot \mathrm{mL}^{-1}\right)$ and incubated at $37^{\circ} \mathrm{C}$ or $90^{\circ} \mathrm{C}$ for different periods of time. The $\mathrm{pH}$ of the degradation medium was monitored during the course of the study. At the end of each time point, the scaffolds were removed from the medium and washed extensively in distilled water. Subsequently, these scaffolds were air-dried up to a constant mass, and then they were characterized by FTIR-ATR analyses, ESEM imaging, as well as through the determination of the water uptake, water contact angle, number average molecular weight between cross-links $\overline{\mathrm{M}}_{\mathrm{c}}$, and mass loss from the scaffold initial mass and their residual mass after drying.

\subsection{Scaffold Colonization by Fibroblasts}

Fibroblasts at passage 7 resuspended in DMEM/Pen (100 IU.mL $\left.{ }^{-1}\right) /$ Strep $\left(100 \mu \mathrm{g} \cdot \mathrm{mL}^{-1}\right)$ supplemented with FBS $(10 \%)$ were seeded onto 24 -well plates at $4 \times 10^{4}$ cells per well. Fibroblasts were cultured at $37{ }^{\circ} \mathrm{C}$ in a humidified atmosphere of $5 \% \mathrm{CO}_{2}$ until an apparent $80 \%$ confluence was reached. Thereafter, the medium was removed, and one scaffold $(1 \mathrm{~cm}$ in diameter, $2 \mathrm{~mm}$ in height) per well was carefully set down over the $80 \%$ confluent cell layer and incubated in DMEM/Pen (100 IU.mL $\left.{ }^{-1}\right) /$ Strep (100 $\left.\mu \mathrm{g} . \mathrm{mL}^{-1}\right)$ supplemented with PRP (5 vol\%) and heparin (2 IU.mL $\left.{ }^{-1}\right)$ at $37^{\circ} \mathrm{C}$ in a humidified atmosphere of $5 \% \mathrm{CO}_{2}$ for up to 35 days. The medium was changed once a week. The scaffolds were tested in triplicate in all experiments.

At 10, 25 and 35 days, the scaffolds were carefully rinsed with PBS and incubated at $37^{\circ} \mathrm{C}$ for $10 \mathrm{~min}$ in a solution of trypsin $(0.05 \%)$ and collagenase $(0.025 \%)$. Thereafter, the supernatant was recovered and centrifuged, and the pellet of cells was resuspended. In order to take off all the cells from the scaffold, this operation is repeated three times. Then, the total number of cells was determined by counting with a Coulter Counter Z1 (Beckman Coulter, Brea, CA, USA) to assess the efficiency of cell migration into the scaffolds.

For ESEM imaging, the scaffolds were rinsed in PBS, fixed in PFA (4\%) and stored in ethanol $70 \mathrm{vol} \%$ up to observation. Images were carried out using a Hitachi TM3000 ESEM operating at $5 \mathrm{kV}$ and equipped with a Peltier stage operating at $-4{ }^{\circ} \mathrm{C}$. For staining, scaffolds were rinsed in PBS, fixed in PFA $(4 \%)$ for $24 \mathrm{~h}$ at $4{ }^{\circ} \mathrm{C}$, and rinsed in distilled water. For Sirius Red staining, scaffolds were immersed in saturated picric acid with $0.1 \%$ Sirius Red for $30 \mathrm{~min}$ and rinsed in distilled water [37]. For cell staining, scaffolds were immersed in hemalun solution $(0.2 \%$ of hematein in $5 \%$ aqueous potassium alum) for $5 \mathrm{~m}$ and rinsed in tap water for $5 \mathrm{~min}$ [38]. Finally, the stained scaffolds were stored in ethanol $70 \mathrm{vol} \%$ up to observation. The scaffold staining was monitored using an Alicona InfiniteFocus microscope (Alicona Imaging GmbH, Raaba/Graz, Austria).

\subsection{Data Analysis}

For the measured parameters of the scaffolds and the in vitro studies, the values are expressed as mean \pm standard deviation (SD). Statistical analysis was performed using the Statistical Package 
for the Social Sciences (SPSS) software. For every population, group normality was checked by the Kolmogorov-Smirnov's test. The homogeneity of variances between the groups was assessed by a Levene's test.

Kruskal-Wallis or Welch's tests were performed for the inspection of any statistical differences between the means. In all statistical evaluations, $\mathrm{p}<0.05$ was considered statistically significant.

\section{Results}

\subsection{PEUUF Scaffolds}

The PEUUF scaffolds were synthesized in a one-step reaction through the cross-linking of a high internal phase emulsion (HIPE) that contained LMW fucoidan in its aqueous phase. When prepared with $34 \mathrm{~mL}$ of a $10 \mathrm{mg} \mathrm{mL}^{-1}$ fucoidan solution, the resulted emulsion had a stable paste-like texture with no phase separation. After the removal of the aqueous internal phase and the washing of the cross-linked scaffolds, foams were obtained with highly interconnected pores without closed voids (Figure $1 \mathrm{~A}, \mathrm{C}$ ). Indeed, the pore interconnectivity was found to be $95.1 \pm 5.3 \%$, indicating that the pores were all very well interconnected. The foams exhibited a high porosity of $83.4 \pm 3.1 \%$ and a multi-scale pore size ranging from 30 to $2000 \mu \mathrm{m}$ with an average pore size of approximately $500 \mu \mathrm{m}$ (Figure 1B,C). Moreover, the surface of the pore walls exhibited a fine rugosity (Figure 1D). The mechanical behavior of the PEUUF scaffolds was determined through compression test (Figure 1E). The compressive stress-strain response of the scaffolds was typical of an elastomeric open-cell foam with three domains: A visco-elastic domain characterized by a linear stress-strain relationship, a post-buckling domain characterized by a long elastic plateau due to pore collapse, a post-complete densification domain where the strain increases rapidly as all the pores have collapsed [39]. The curve slope in the visco-elastic domain allowed the determination of the effective elasticity modulus $E_{1}$ *o the PEUUF scaffold, which was found to be $103 \pm 23 \mathrm{kPa}$.
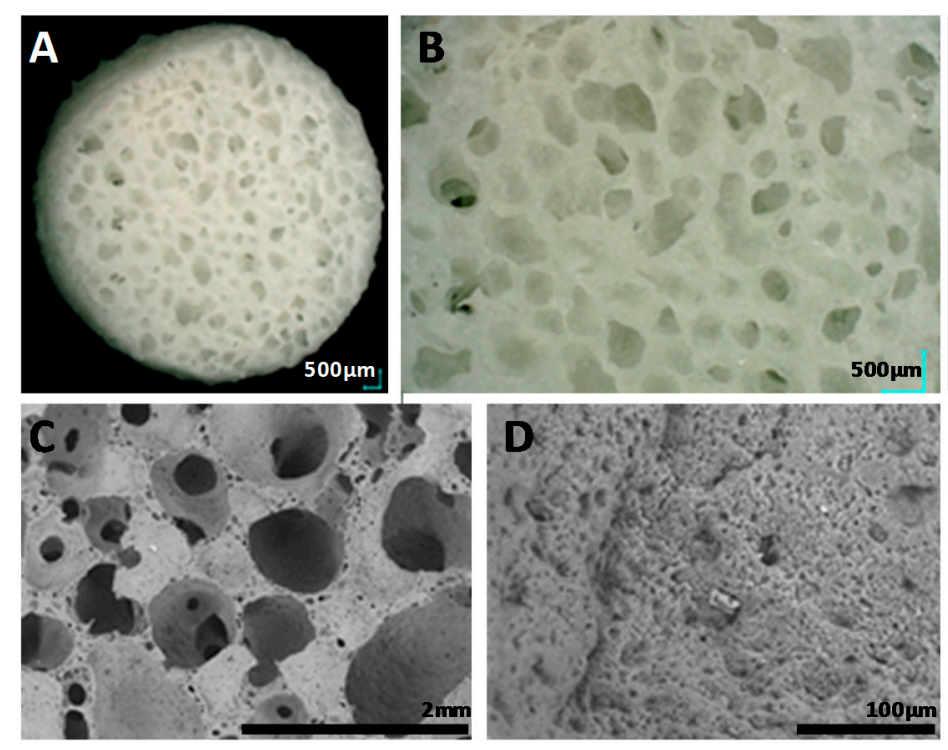
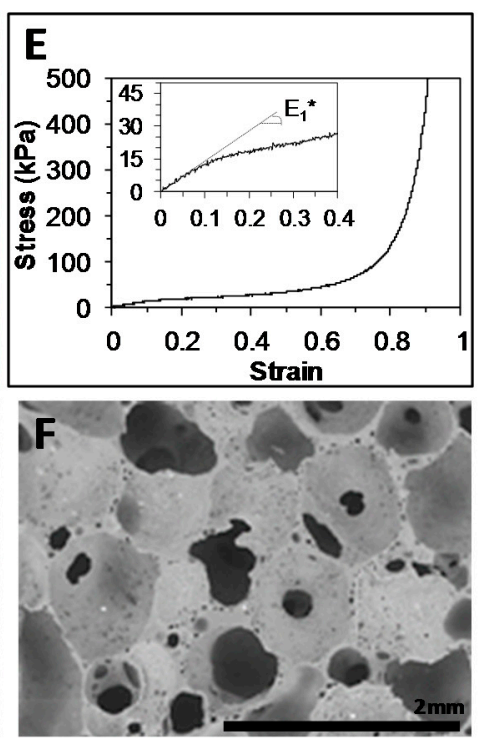

Figure 1. (A,B): Digital microscope images of functionalized-poly(ester-urea-urethane) scaffolds (PEUUF) scaffolds. (C,D): Environmental scanning electron microscope (ESEM) images of PEUUF scaffolds. E: Mechanical behavior of PEUUF scaffolds under stress modes of compression. F: ESEM image of PEUUF scaffolds after 7 months of incubation at $37^{\circ} \mathrm{C}$ in the degradation medium. The low-molecular-weight (LMW) fucoidan concentration in the aqueous phase ( $34 \mathrm{~mL}$ ) of the High Internal Phase Emulsion (HIPE) used for functionalization $=10 \mathrm{mg} \mathrm{mL}^{-1}$ ).

The LMW fucoidan immobilization inside the scaffold was obtained in a very homogeneous way throughout the scaffold thickness (Figure 2B), and it was clear that the complexation of toluidine blue 
onto the PEUUF scaffold was only due to the presence of LMW fucoidan, as a scaffold prepared without fucoidan in the emulsion remained nearly colorless (Figure 2A). The fucoidan immobilization inside the scaffold increased as the concentration of fucoidan in the aqueous phase of the HIPE increased up to $10 \mathrm{mg} \mathrm{mL}^{-1}$ (Figure $2 \mathrm{C}$ ).
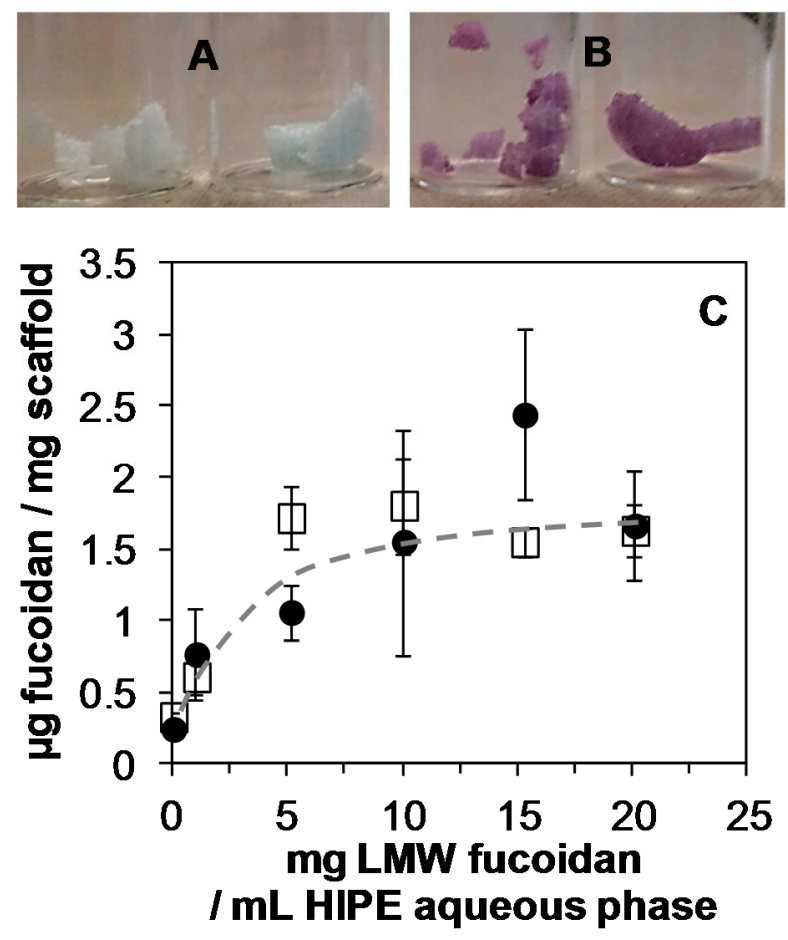

Figure 2. A,B: Scaffold staining (after washing) due to complexation of toluidine blue with LMW fucoidan for the fucoidan concentration in the HIPE aqueous phase $(34 \mathrm{~mL})$ of $0 \mathrm{mg} \mathrm{mL}^{-1}(\mathbf{A})$ and $10 \mathrm{mg} \mathrm{mL}^{-1}$ (B). C: Amount of LMW fucoidan immobilized inside scaffolds before ( $\square$ ) and after washing (•) as a function of the LMW fucoidan concentration in the HIPE aqueous phase.

Higher fucoidan concentration in the HIPE did not lead to an increase in the fucoidan immobilization, which reached around $1.6 \mu \mathrm{g}$ per $\mathrm{mg}$ of scaffold. It was also found that varying the aqueous phase content in the HIPE impacted the amount of immobilized fucoidan. Indeed, $1.27 \pm 0.1$ and $2.16 \pm 0.3 \mu \mathrm{g}$ of fucoidan per mg of scaffold were measured when the HIPE was prepared, respectively, with $20 \mathrm{~mL}$ and $50 \mathrm{~mL}$ of a $10 \mathrm{mg} \mathrm{mL}^{-1}$ fucoidan aqueous solution. However, the modification of the aqueous phase content in the HIPE impacted the pore sizes. As a consequence, a concentration of fucoidan of $10 \mathrm{mg} \mathrm{mL}^{-1}$ and an aqueous phase content of $34 \mathrm{~mL}$ in the HIPE were chosen for the bio-activation study. Finally, the fucoidan immobilization was stable after the scaffold washing (Figure 2C).

The fucoidan immobilization was also put in evidence through FTIR-ATR analysis (Figure 3A). The spectrum of the PEUUF scaffold presented the significant bands of poly(ester-urea-urethane)-based materials, such as urethane hydrogen-bonded $-\mathrm{NH}$ stretching at $3333 \mathrm{~cm}^{-1},-\mathrm{C}=\mathrm{O}$ groups for urethane and ester at $1730 \mathrm{~cm}^{-1}$ and for urea at $1620 \mathrm{~cm}^{-1}$, urea $-\mathrm{CNH}$ groups at $1575 \mathrm{~cm}^{-1}$ and urethane $-\mathrm{NH}$ bending at $1537 \mathrm{~cm}^{-1},-\mathrm{CN}$ stretching and $-\mathrm{NH}$ bending associated with urethane groups at $1248 \mathrm{~cm}^{-1}$, and finally the stretching vibrations of the ester groups at $1164 \mathrm{~cm}^{-1}$ [33]. In addition, the PEUUF scaffold exhibited two bands at $840 \mathrm{~cm}^{-1}$ and $819 \mathrm{~cm}^{-1}$ associated with a C-O-S stretching of the fucoidan sulfate groups $[40,41]$. The subtracted spectrum also put in evidence two more bands typical for polysaccharides at $1612 \mathrm{~cm}^{-1}$ due to the in-plane ring $\mathrm{CCH}, \mathrm{OCH}$ and $\mathrm{COH}$ vibrations and at $733 \mathrm{~cm}^{-1}$ for the $\mathrm{C}-\mathrm{O}-\mathrm{S}$ stretching of the sulfate groups [42,43]. Finally, the presence of fucoidan inside the scaffold modified the surface wettability, since the water contact angle of PEUUF scaffolds 
was found to be $79 \pm 4^{\circ}$ by comparison with $96 \pm 10^{\circ}$ for any scaffolds synthesized in the absence of fucoidan.
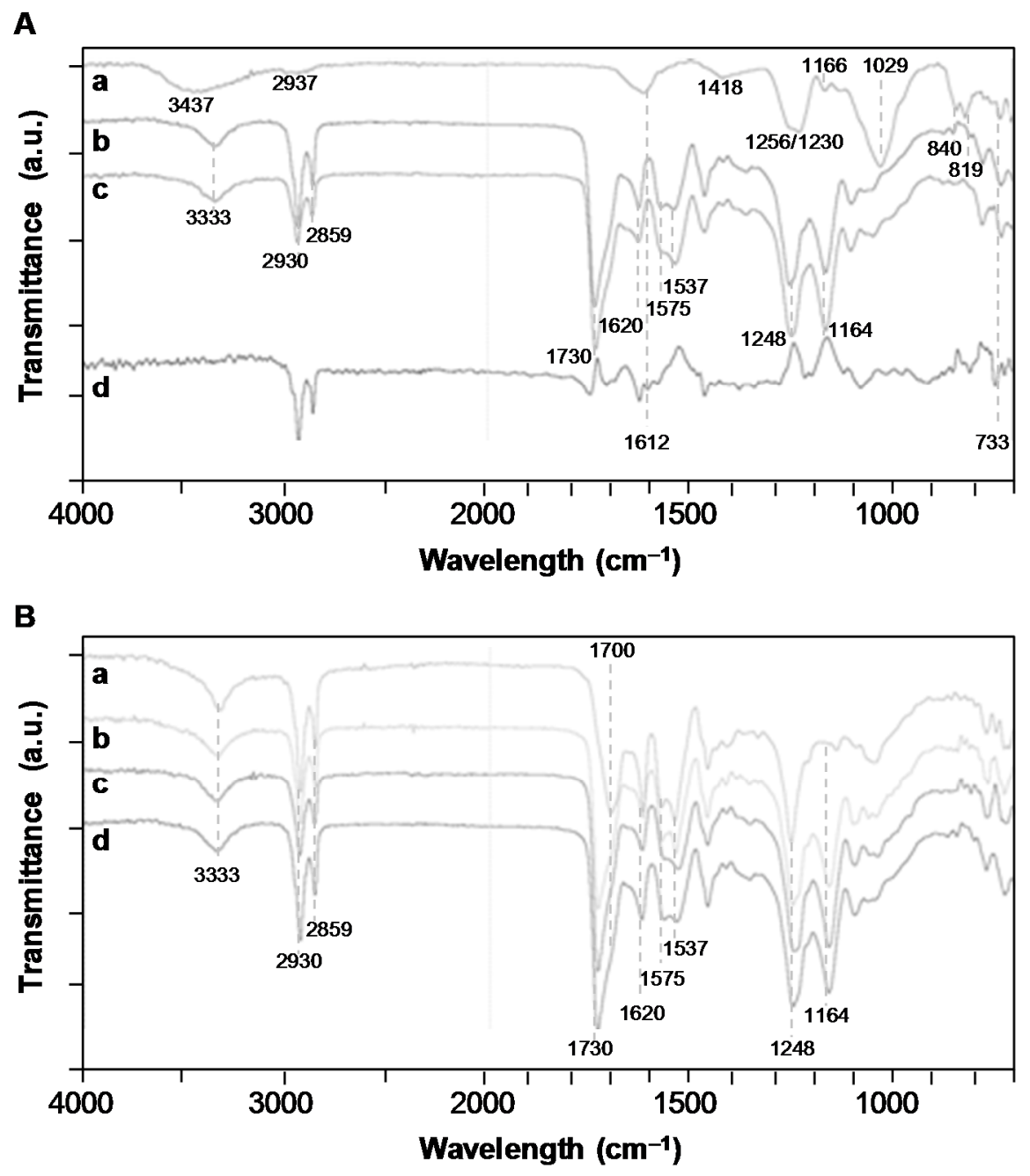

Figure 3. A: Fourier-transformed infrared (FTIR)-attenuated total reflection (ATR) spectroscopy spectra of a/LMW fucoidan; b/PEUUF scaffold; c/Non-functionalized scaffold synthesized in absence of fucoidan; $\mathrm{d} /$ Subtraction spectrum of functionalized and non-functionalized scaffolds. B: FTIR-ATR spectra of a/PEUUF scaffold after 70 days of incubation at $90{ }^{\circ} \mathrm{C}$ in the degradation medium; $\mathrm{b} / \mathrm{PEUUF}$ scaffold after 11 days of incubation at $90{ }^{\circ} \mathrm{C}$ in the degradation medium; c/PEUUF scaffold after 7 months of incubation at $37^{\circ} \mathrm{C}$ in the degradation medium; d/PEUUF scaffold before incubation in the degradation medium. (The LMW fucoidan concentration in the aqueous phase of the HIPE used for functionalization $=10 \mathrm{mg} \mathrm{mL}^{-1}$ ).

The stability of the functionalization was studied by quantifying the amount of fucoidan remaining inside the scaffold after washing, sterilization and incubation in PBS during 7 days and 30 days (Figure 4). There was no statistically significant difference in the amount of fucoidan between the adsorption and functionalization methods either before or after washing $(\mathrm{p}=0.560)$. No fucoidan remained inside the scaffold after sterilization and 7 days of incubation in PBS when fucoidan was only adsorbed after the scaffold elaboration $(\mathrm{p}=0.203$ between incubated scaffolds containing adsorbed fucoidan and scaffolds synthesized in an absence of fucoidan). Notwithstanding, the functionalization developed in this study was stable, since no statistically significant difference in the amount of immobilized fucoidan was found after the washing of PEUUF scaffolds and after sterilization and 7 days of incubation in PBS $(p=0.085)$. After 30 days of incubation in PBS, the amount of immobilized fucoidan slightly decreased $(\mathrm{p}=0.035)$, but was still statistically significantly higher than scaffolds synthesized in the absence 
of fucoidan $(p=0.035)$ and scaffolds containing adsorbed fucoidan after sterilization and 7 days of incubation in PBS $(\mathrm{p}=0.031)$.

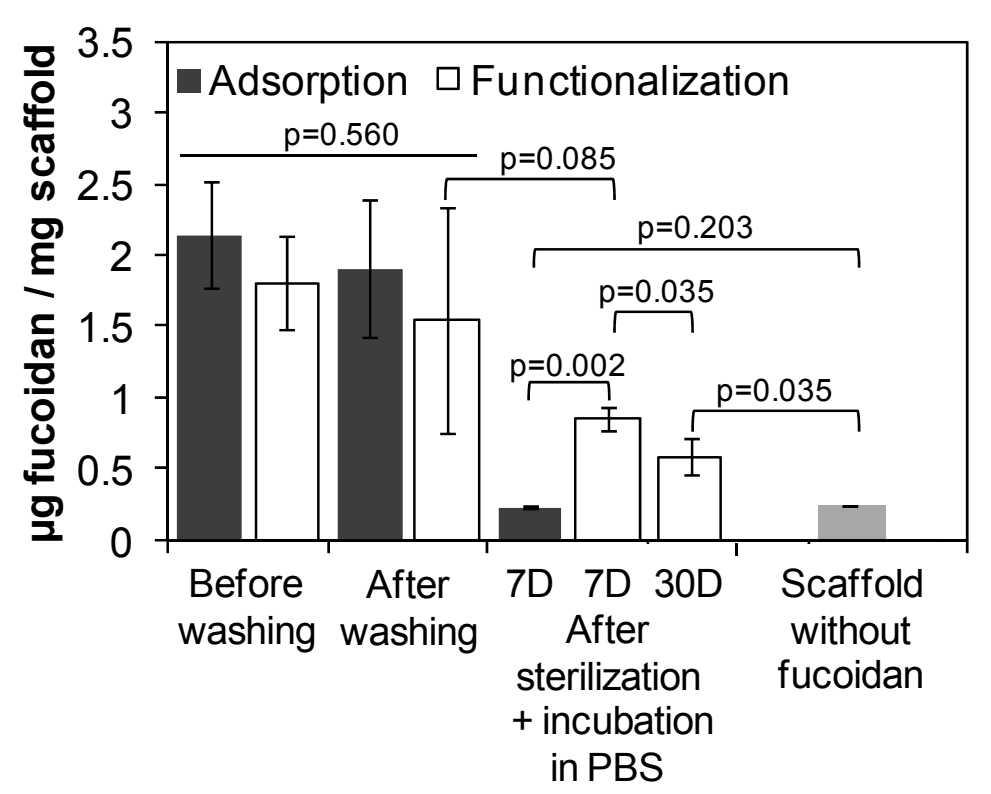

Figure 4. Amount of LMW fucoidan immobilized inside scaffolds when adsorbed after the scaffold elaboration (adsorption), or when directly incorporated during the scaffold elaboration (functionalization) before washing, after washing and after incubation in PBS by comparison with scaffolds synthesized in the absence of fucoidan. (The LMW fucoidan concentration in the aqueous phase used for adsorption or functionalization $=10 \mathrm{mg} \mathrm{mL}^{-1}$ ).

The stability of PEUUF scaffolds was studied for up to 7 months in the DMEM medium at $37^{\circ} \mathrm{C}$. No variation in scaffold mass, water uptake and water contact angle was noticed (Figure 5A,C). No release of acidic degradation products was evidenced, since there was no variation of the medium $\mathrm{pH}$ (Figure 5B). However after 7 months of incubation, a very small variation of the PEUUF composition was detected by an FTIR-ATR analysis through a decrease of $2.8 \%$ of the intensity of the peak at $1164 \mathrm{~cm}^{-1}$, corresponding to the stretching vibrations of the ester groups (Figure 3B). An increase in the number average molecular weight between cross-links $\overline{\mathrm{M}}_{\mathrm{c}}$ due to chain scissions was also noticed (Figure 5D). Moreover, the porosity slightly decreased after 7 months of incubation $(78.4 \pm 1.1 \%)$, while no significant variation of the porous morphology of the PEUUF scaffold was evidenced (Figure 1F). Finally, an accelerated aging was also performed at $90{ }^{\circ} \mathrm{C}$. At this degradation temperature, it was noticed that mass loss started to occur after 11 days of incubation (Figure 5A) that led to a decrease or the impossibility to measure the number average molecular weight between cross-links $\overline{\mathrm{M}}_{\mathrm{c}}$ (Figure 5D), because the scaffold became very brittle. An increase of the water uptake (Figure 5A) and a drastic decrease of the water contact angle (Figure 5C) were also noticed, which was in accordance with the FTIR-ATR analysis (Figure 3B). Indeed, the peak at $1164 \mathrm{~cm}^{-1}$ of the ester groups decreased by $11.3 \%$ after 11 days of incubation in the degradation medium, and up to $71.8 \%$ after 70 days. Acidic degradation products were released during the degradation, as attested by the variation of the medium $\mathrm{pH}$ (Figure 5B). Overall, it was possible to conclude that the PEUUF scaffold life-time at $90{ }^{\circ} \mathrm{C}$ was approximately 11 days. The scaffold life-time at $37^{\circ} \mathrm{C}$ was estimated to be that of the scaffold life-time at $90^{\circ} \mathrm{C}$ multiplied by the factor $f$ ranging from 39.4 to 128.6 as calculated by Equation (2) [44]:

$$
f=\mathrm{Q}_{10}^{\Delta \mathrm{T} / 10}
$$

In Equation (2), $\Delta \mathrm{T}$ is the difference between the elevated temperature used to accelerate the degradation process $\left(90^{\circ} \mathrm{C}\right)$, and the temperature at which to study the effects of degradation $\left(37^{\circ} \mathrm{C}\right)$; 
the aging factor $\mathrm{Q}_{10}$ was taken as 2-2.5 in accordance with the ASTM F1980-16 standard. Therefore, the PEUUF scaffold life-time at $37^{\circ} \mathrm{C}$ was estimated to range between 14.2 and 46.5 months.

A

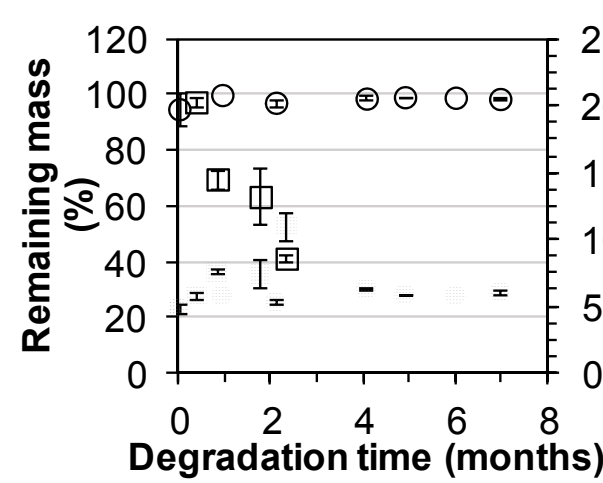

C

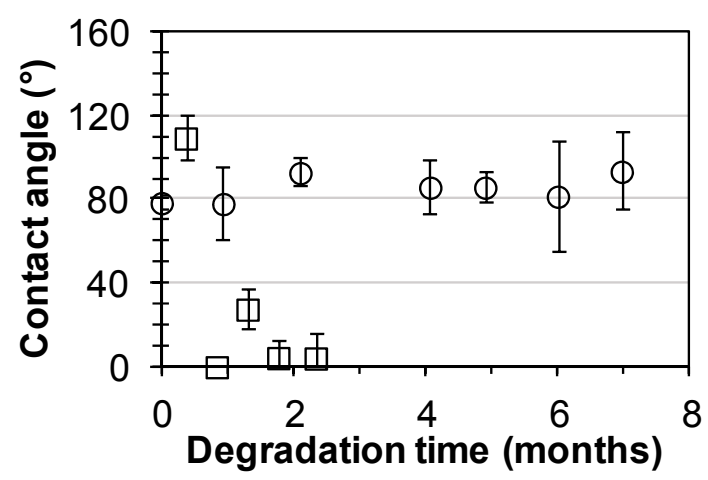

B

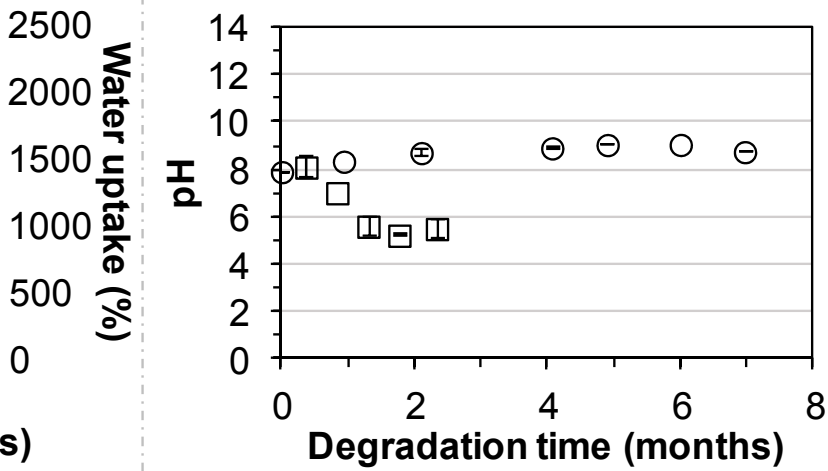

D

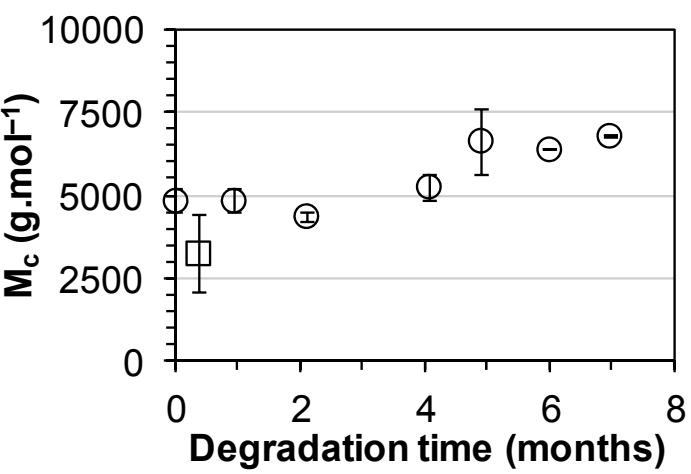

Figure 5. Incubation of PEUUF scaffolds in the degradation medium at $37^{\circ} \mathrm{C}(\bigcirc)$ and $90{ }^{\circ} \mathrm{C}(\square)$ over a period of 7 months and 70 days, respectively: (A) Scaffold remaining mass (open symbols) and water uptake (full symbols); (B) Medium pH; (C) Water contact angle; (D) Scaffold number average molecular weight between cross-links $\overline{\mathrm{M}}_{\mathrm{c}}$. (The LMW fucoidan concentration in the aqueous phase of the HIPE used for functionalization $=10 \mathrm{mg} \mathrm{mL}^{-1}$ ).

\subsection{PEUUF Scaffold Bio-Activation with PRP}

The scaffold bio-activation with PRP was carried out by impregnation after the sterilization of the PEUUF scaffolds. Biomolecules from PRP readily penetrated into the scaffold, and the density of the PRP adsorption depended on the scaffold immersion time in the PRP solution, as well as on the solution concentration. When incubated in a $15 \mathrm{vol} \%$ PRP solution, the scaffold bio-activation increased as the incubation time increased up to nearly $5 \mathrm{~h}$ (Figure 6C). A higher incubation time did not lead to an increase in the PRP adsorption, which reached around $4.7 \mu \mathrm{g}$ per $\mathrm{mg}$ of scaffold. Moreover by this adsorption method, a biological frame covering the pore walls was obtained after $16 \mathrm{~h}$ of incubation in all tested PRP concentrations (10,15 and $20 \mathrm{vol} \%$ ) (Figure 6A). In addition, for a PRP concentration of $15 \mathrm{vol} \%$, a fibrillar network appeared across pores while maintaining the open porosity of the scaffold (Figure 6B). When increasing the PRP concentration to $20 \mathrm{vol} \%$, a thick hydrogel surrounded the scaffold and led to pore closure. As a consequence, the concentration of PRP used for the bio-activation was chosen to be $15 \mathrm{vol} \%$ for the in vitro assays.

The PRP adsorption was also put in evidence through an FTIR-ATR analysis and by contact angle and water uptake measurements. The presence of PRP increased the hydrophilicity of the scaffold, since the water contact angle decreased from $79 \pm 4^{\circ}$ for PEUUF scaffolds to $32 \pm 44^{\circ}$ for PRP bio-activated ones (PRP-PEUUF). It has to be pointed out that the water drop spread slowly on 
PRP-PEUUF scaffolds. Moreover, the water uptake was determined by immersing dry scaffolds for $24 \mathrm{~h}$ in distilled water. It was found that the water uptake was enhanced from $277 \pm 22 \%$ for the PEUUF scaffold to $367 \pm 5 \%$ for the PRP-PEUUF ones. The FTIR-ATR analysis of those PRP-PEUUF scaffolds presented the significant bands of PEUUF, and also exhibited bands from proteins present in PRP, such as the amide I and II groups of the peptide bond at respectively, $1650 \mathrm{~cm}^{-1}$ and $1542 \mathrm{~cm}^{-1}$, the bending of $\mathrm{CH}_{2 / 3}$ groups present in amino acid side chains at $1400 \mathrm{~cm}^{-1}$, as well as the broadening of the band centered at $3293 \mathrm{~cm}^{-1}$ assigned to the protein NH groups (Figure 7) [45].

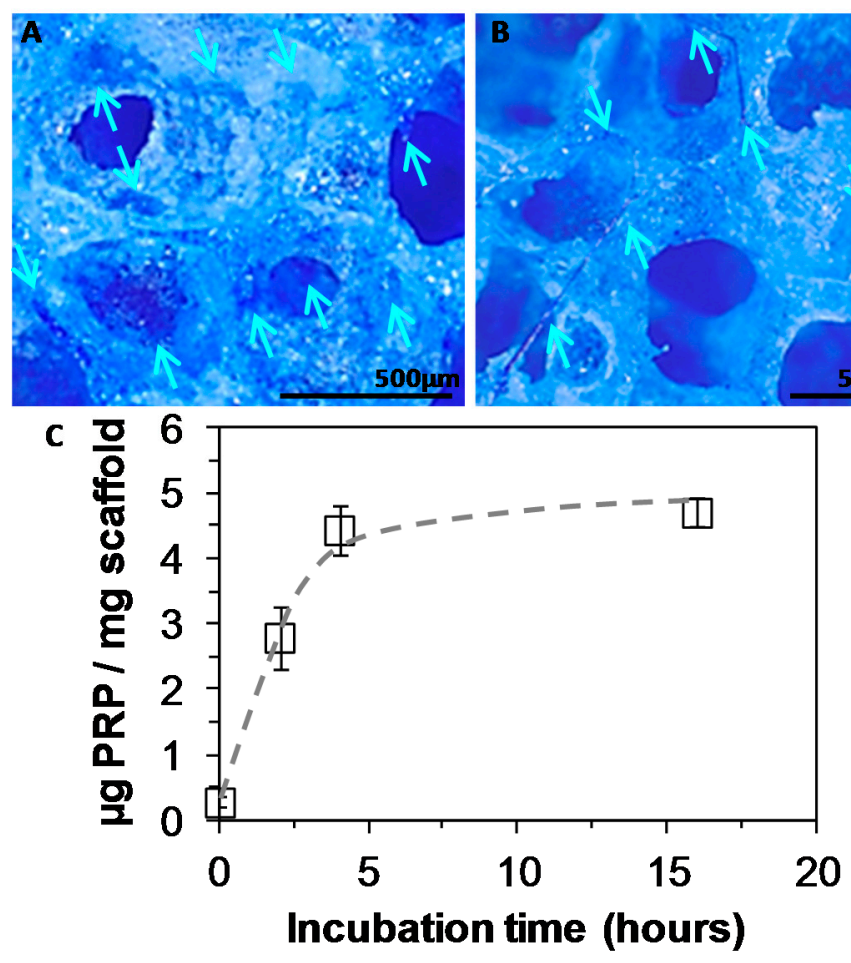

Figure 6. A,B: Staining of platelet rich plasma (PRP) adsorbed into PEUUF scaffolds due to complexation with Coomassie blue (PRP concentration used for bio-activation $=15 \mathrm{vol} \%$ (16 h of incubation)) (Arrows indicate some locations of PRP in images). C: Amount of PRP adsorbed into PEUUF scaffolds as a function of incubation time in a $15 \mathrm{vol} \%$ PRP solution (The LMW fucoidan concentration in the aqueous phase of the HIPE used for functionalization $\left.=10 \mathrm{mg} \mathrm{mL}^{-1}\right)$.

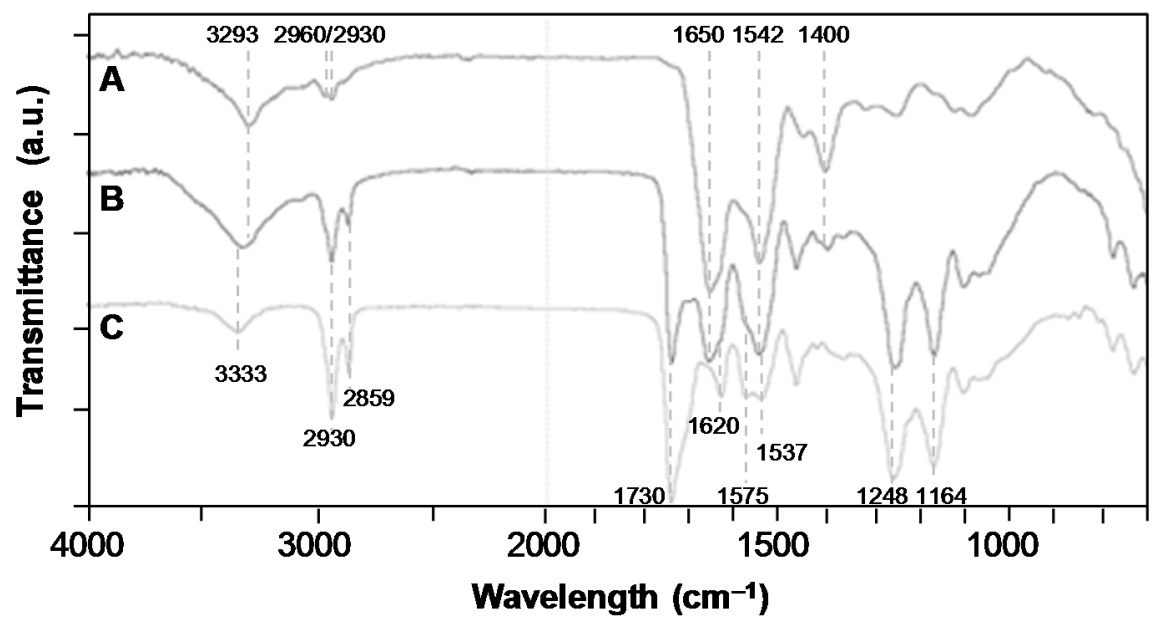

Figure 7. FTIR-ATR spectra of: A/Pure PRP (dry); B/PRP-PEUUF scaffold (dry); C/PEUUF scaffold (the LMW fucoidan concentration in the aqueous phase of the HIPE used for functionalization = $10 \mathrm{mg} \mathrm{mL}^{-1}$; and the PRP concentration used for bio-activation $=15 \mathrm{vol} \%$ ( $16 \mathrm{~h}$ of incubation)). 


\subsection{Cell Responses towards PEUUF and PRP-PEUUF Scaffolds}

The capability of scaffolds to recruit cells was carried out through migration assays by setting down scaffolds over a confluent cell layer. It was noticed that fibroblasts were able to migrate into the porous structure of both PEUUF and PRP-PEUUF scaffolds (Figure 8). However, the bio-activation with PRP drastically improved the cell recruitment and migration, since more cells were found in PRP-PEUUF scaffolds, as attested by the statistically significant difference of the cell number at each day of migration ( $p<0.001$ at 10 days, $p=0.006$ at 20 days and $p=0.001$ at 35 days). Moreover, the cell number increased continuously with migration time into the PRP-PEUUF scaffolds, while there was no statistically significant difference for the PEUUF scaffolds between 20 and 35 days of migration $(\mathrm{p}=0.216)$.

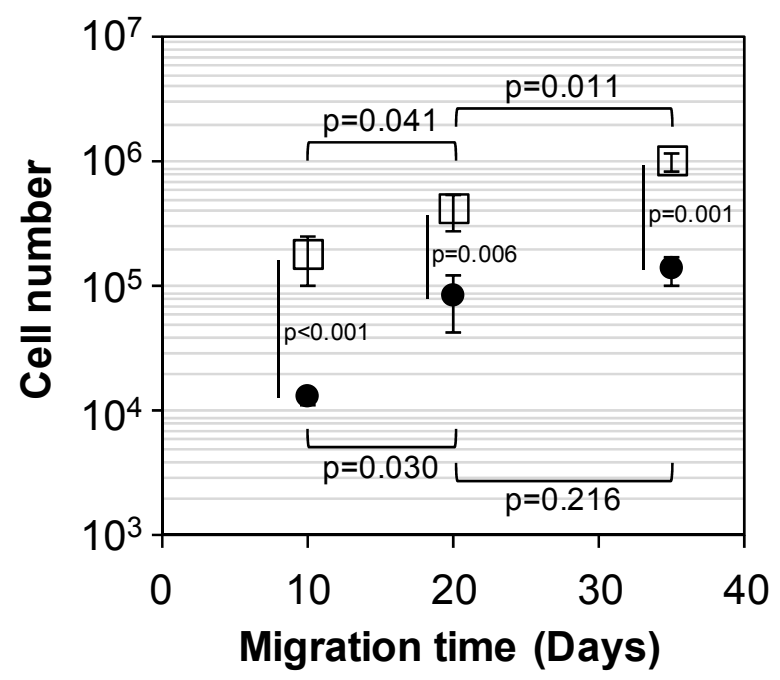

Figure 8. Cell number after 10, 20 and 35 days of fibroblast migration into PEUUF scaffolds (๑) and PRP-PEUUF scaffolds ( $\square$ ) (the LMW fucoidan concentration in the aqueous phase of the HIPE used for functionalization $=10 \mathrm{mg} \mathrm{mL}^{-1}$; the PRP concentration used for bio-activation $=15 \mathrm{vol} \%(16 \mathrm{~h}$ of incubation)).

For PEUUF scaffolds, few cells were found within the scaffold after 10 days of migration (Figure 9F); and after 35 days, fibroblasts mostly attached to the surface of the pore walls (Figure 9G,I) and spread over them in an elongated pattern (Figure $9 \mathrm{H}$ ). As expected from the cell number results, more fibroblasts were found inside the PRP-PEUUF scaffold from 10 days of migration (Figure $9 \mathrm{~K}, \mathrm{~L}, \mathrm{~N}$ ). Moreover, cells both attached and spread over the pore wall surface and interacted with all pore sides, leading to the bridging of cell layers across pores (Figure 9L,M). After 35 days of migration, the fibroblasts in the PRP-bio-activated and LMW-functionalized scaffold exhibited a higher staining of the collagenous matrix arranged in a more homogeneous network (Figure 9J,O). Furthermore, it has to be pointed out that, if cells were able to infiltrate and to attach on the pore walls of non-functionalized scaffolds synthesized in the absence of fucoidan and impregnated with PRP (Figure 9A,C,D), the 3D arrangement of these cells inside the scaffold porous structure and the increase of the collagen deposit were not found (Figure 9B,E), attesting the synergic effect of the scaffold functionalization by the LMW fucoidan and its bio-activation by PRP on the cell response. 

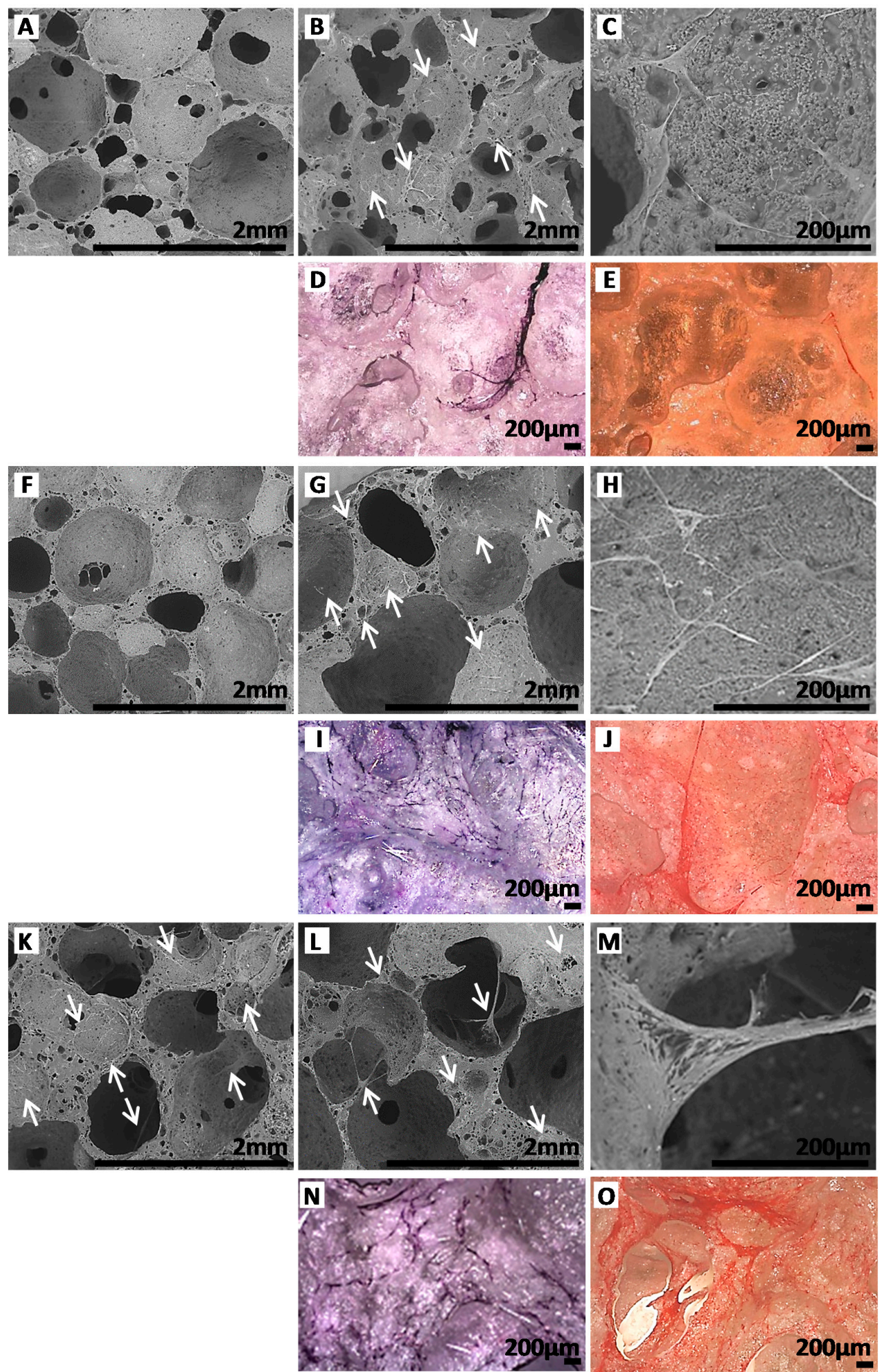

Figure 9. ESEM images of scaffolds after $10(\mathbf{A}, \mathbf{F}, \mathbf{K})$ and $35(\mathbf{B}, \mathbf{C}, \mathbf{G}, \mathbf{H}, \mathbf{L}, \mathbf{M})$ days of fibroblast migration (Arrows indicate some locations of cells in ESEM images). Images after 35 days of fibroblast migration of scaffolds stained with Hemalun (D,I,N) and Sirius red (E,J,O). A,B,C,D,E: Non-functionalized scaffolds synthesized in absence of fucoidan and impregnated with PRP. F,G,H,I,J: PEUUF scaffolds. K,L,M,N,O: PRP-PEUUF scaffolds. (The LMW fucoidan concentration in the aqueous phase of the HIPE used for functionalization $=10 \mathrm{mg} \mathrm{mL}^{-1}$; while the PRP concentration used for bio-activation $=15 \mathrm{vol} \%(16 \mathrm{~h}$ of incubation)). 


\section{Discussion}

To overcome the limitations of classical tissue engineering based on cell seeding onto scaffolds, cell-free approaches have been investigated, and the use of a cell-free scaffold as an off-the-shelf product presents a more reliable and foreseeable clinical solution [2,46-49]. Nevertheless, the use of cell-free scaffolds relies on the elaboration of a biomaterial capable of recruiting and guiding resident cells to stimulate tissue development. Since the interactions between a scaffold and the cells are mediated by the biomaterial surface energy, surface topography, surface functionality and surface stiffness, tissue regeneration requires the optimal combination of an optimized scaffold and biological cues [50]. The purpose of this study was to investigate the design, through a straightforward manufacturing and shaping method, of an elastomeric scaffold suitable for soft-tissue engineering, with an appropriate surface chemistry allowing the retention of biomolecules that can direct cellular processes. After the elaboration of PEUUF scaffolds, biological cues were introduced through bio-activation by PRP formulations.

\subsection{PEUUF Scaffolds as Biomaterials for Soft-Tissue Engineering}

Fucoidan is a natural anionic sulfated polysaccharide extracted from brown Algae that has been extensively studied in recent years, due to its numerous biological properties, such as anti-tumor, anti-coagulant, anti-thrombotic, anti-inflammatory and anti-oxidant effects [28,32,51,52]. As a matter of fact, the properties of these polysaccharides depend on their electrical charges, sulfation degree and molecular weight $[25,53,54]$. It has been demonstrated that low-molecular-weight fucoidans exhibit therapeutic potential in tissue engineering because fucoidans can influence cell adhesion, migration, proliferation and differentiation $[25,52,55]$. Indeed, fucoidans are able to bind growth factors providing an appropriate environment for cell migration and proliferation; and to regulate their bioavailability, which is of great interest for tissue engineering applications [56-59]. For instance, LMW fucoidans enhance FGF-2 activity, mobilize SDF-1 and promote in vivo angiogenesis [25]. Interestingly, LMW fucoidans also allow the protection of extracellular matrix and growth factors against proteolysis $[27,60]$.

In our study, LMW fucoidan was easily immobilized during the scaffold elaboration using the HIPE method. HIPEs are characterized by a network of the droplet interfaces, the properties of which will determine the properties of the resulting scaffold [61]. As a consequence, the HIPE water-oil interface might provide opportunities to tune scaffold properties. Indeed, the poly(ester-urea-urethane) matrix was synthesized by a one-step polycondensation reaction between the isocyanate groups of the cross-linker and the alcohol groups of the caprolactone oligomers, which were contained in the organic continuous phase of the water-in-oil HIPE. During the scaffold elaboration, the LMW fucoidan, which was introduced in the aqueous phase, might readily be entrapped in the poly(ester-urea-urethane) matrix, or react via its hydroxyl groups with the isocyanate moities incorporated in excess in the emulsion. Since the fucoidan was in the aqueous phase, only a small amount can be incorporated at the HIPE water-oil interface. This point was attested by the increase of fucoidan immobilization in PEUUF scaffolds with the amount of aqueous phase in the HIPE formulation. The advantage of HIPE for scaffold fabrication is the control over porosity and pore size, as well as the interconnectivity through the modification of the internal phase volume fraction [33]. As a consequence for our study, the amount of the fucoidan solution $(84 \mathrm{vol} \%)$ incorporated in the HIPE was dictated by the targeted scaffold morphology. The fucoidan molecular weight might also have an impact on the fucoidan immobilization. For instance, it was demonstrated that when polysaccharide electrospun fibers were elaborated in the presence of fucoidan, the content of immobilized fucoidan increased with its molecular weight $[23,24]$. Nevertheless, better growth factor retention was found for molecular weight in the range $20-40 \mathrm{kDa}$. Moreover, it has to be point out that HIPE relies on the droplet deformation by surface droplet stretching and the formation of plateau borders [61].

To provide stability, HIPE interface strength can be increased by using interfacial proteins. However, an enhanced rigidity of the droplets may prevent droplet deformation [62]. With the aim of developing a scaffold possessing a highly optimal porous structure appropriate for tissue 
development, and containing chemical groups that could retain biomolecules through ionic interactions, and potentially protect them against proteolytic degradation, PEUUF scaffolds were designed, favoring the use of more flexible LMW fucoidan with molecular weight in the range 16-20 kDa, and a high sulfation degree ( $40 \mathrm{wt} \%$ sulfate). By this elaboration method, the scaffold functionalization was obtained homogeneously in a very versatile and stable way. The amount of immobilized fucoidan, around $1.6 \mu \mathrm{g}$ per $\mathrm{mg}$ of scaffold, was in the range of similar results reported from the literature for heparin and heparin-mimicking polymer functionalized scaffolds that exhibited growth factor retention properties and cell response modulating effects $[23,24,36,63]$.

After scaffold elaboration, one critical task in the tissue engineering field is to find an appropriate sterilization process capable of achieving effective sterilization without leading to adverse post-sterilization effects. Steam sterilization is one of the most extensively used methods for biomaterial sterilization because it is effective, fast and simple. However, it can affect the strength, molecular weight and structural properties of biodegradable scaffolds [64]. In a previous study, we developed a method in order to steam sterilize under wet conditions poly(ester-urea-urethane)-based scaffolds without high adverse post-sterilization effects [34]. Here again, the micro-structural properties of PEUUF scaffolds was not affected by the sterilization process. Moreover, the fucoidan functionalization was stable after sterilization, and fucoidan was still present within the scaffold after 30 days of incubation in PBS. Concerning the in vitro scaffold stability at $37^{\circ} \mathrm{C}$, PEUUF scaffolds were quite stable for up to 7 months of incubation in the degradation medium. To estimate the over long timescale of scaffold degradation, accelerated aging was performed at $90^{\circ} \mathrm{C}$, and allowed to estimate the PEUUF scaffold life-time at $37^{\circ} \mathrm{C}$ in the range of $14.2-46.5$ months. The enhanced wettability of PEUUF scaffolds, due to the fucoidan immobilization, increased the degradation rate by comparison with non-functionalized scaffolds which exhibited a life-time at $37^{\circ} \mathrm{C}$ in the range of 19.4-63.4 months [34]. It is well known that scaffold life-time is reduced in vivo because of more severe conditions. However, PEUUF scaffolds seem to be sufficiently stable for their used in soft-tissue engineering applications [65]. Obviously, the long term in vivo scaffold stability has to be confirmed by deep investigations, in particular to ascertain that the PEUUF scaffold degradation does not lead to a stimulation of inflammatory or immune systems.

\subsection{PEUUF Scaffolds Allow Cell infiltration}

The interactions between a scaffold and cells are mediated by the biomaterial surface energy, surface topography, surface functionality and surface stiffness [50]. As a consequence, the structural and physico-chemical characteristics of scaffolds are of high importance for the guiding of cell behavior. For cell-free based-tissue engineering approaches, the scaffold must induce cells to attach themselves to the biomaterial and migrate into the scaffold thickness. First of all, scaffold surface hydrophobicity is a key factor for cell adhesion. Indeed, cell adhesion molecules tend to absorb at higher levels onto hydrophobic surfaces. For instance, there was reported a maximal protein absorption and fibroblast adhesion towards biomaterials exhibiting water contact angles in the range $60^{\circ}-80^{\circ}$ [66]. Secondly, surface charge also impacts cell attachment, and anionic sulfated polysaccharides are known to influence cell adhesion, migration, proliferation and differentiation through their ability to bind proteins, such as growth factors, proteases, and chemokines [25,52,55]. Concerning surface roughness, it was found that the effect depends on the cell type. Fibroblasts adhere to various surface roughness, but exhibit different morphologies. Indeed, fibroblasts spread with a flattened shape onto smooth surfaces, while the morphology is affected by the surface grooves for rough surfaces [67]. Scaffolds with architecture at the microscopic level provide a framework for cell attachment and distribution in the 3D micro-environment, since sub-cellular structure controls cell-cell inter-relationships [66]. Finally, cells are sensitive to the matrix stiffness, and scaffolds mechanically compatible with the tissue to replace, are favored.

Indeed, stress concentrations tend to increase at the tissue-scaffold interface when the biomaterial is too stiff, while a mechanical failure occurs for a too weak scaffold. In addition, cells routinely contract 
to pull on the biomaterial to which they are attached [68-70]. For instance, fibroblasts contract when they spread and elongate to migrate into a scaffold. It was demonstrated that fibroblasts are able to generate contractile forces up to the order of hundreds of nanonewtons [68,71]. As a consequence, the cellular response depends on the scaffold capacity to accommodate deformation, and biodegradable elastomeric scaffolds find applications in soft-tissue repair [65,69]. In our study, PEUUF scaffolds exhibited a water contact angle around $79^{\circ}$, a functionalized surface with anionic sulfated fucoidan, microscopic pores and a pore wall roughness. With regards to all these parameters, PEUUF scaffolds seem appropriate for fibroblast adhesion and infiltration. Moreover, PEUUF scaffolds exhibited a great elastomeric behavior with a short linear region (strain $<0.1$ ), a prolonged elastic buckling plateau (strain from 0.1 to 0.5 ) and a post-complete densification domain at very large strains. Finally, PEUUF scaffold morphology recovered upon removal of the load (data not shown). Therefore, PEUUF scaffolds might accommodate large deformation by buckling, making them appropriate for soft-tissue engineering.

PEUUF scaffolds exhibited a highly interconnected porous structure (porosity of around $83 \%$ ) with a multi-scale pore size from microscopic to macroscopic pores, with an average pore size of $500 \mu \mathrm{m}$. Literature reports scaffold elaboration with various pore sizes, ranging from $20 \mu \mathrm{m}$ to $1500 \mu \mathrm{m}$, with a generally average pore size below $500 \mu \mathrm{m}$, but a high porosity, and a multi-scale pore size might be an advantage in promoting cell migration and further tissue ingrowth [66,69]. As a matter of fact, high interconnectivity and permeability (increasing with pore size) are crucial for the provision of oxygen and nutrients maintaining cell viability in the scaffold inner regions. Pore size and interconnectivity also influence the cell adhesion and migration rate. Indeed, small pores are essential for initial cell attachment, due to an increase in the specific surface area with decreasing pore size [72,73]. The optimal pore size for cell infiltration depends upon the cell type, and it was demonstrated that fibroblasts preferentially attach to scaffolds with pore sizes below $160 \mu \mathrm{m}$, and fibroblast migration decreases as pore size increases from 90 to $150 \mu \mathrm{m}$, due to a more available adhesive ligand density $[66,69,70,74]$. However when pores are too small, cell infiltration is limited at the scaffold outer surface restricting cell migration towards the scaffold center due to a limitation in the cell movement direction. The cellular aggregation at the scaffold edge limits nutrient and oxygen diffusion, as well as waste removal, resulting in necrotic cores inside the scaffold $[69,70,72,73]$. With larger pores above $300 \mu \mathrm{m}$ and high interconnectivity, cell migration into the scaffold and migration speed are enhanced. Moreover, the cell spreading over the pore walls is more effective, and cells exhibit an elongated pattern that is known to be important for directed cell migration and persistent motion. Indeed, it was demonstrated that cell speed at pore wall junctions is lower than the speed along the pore walls regardless of the pore size. As a consequence, high interconnectivity and large pores enhance cell speed, since the time spent at pore wall junctions is decreased $[69,73,75,76]$. In addition, if cell speed decreases when cells travel on larger pores, cells travel further into the scaffold due to a less erratic and more directional movement. As a consequence, the importance of high specific surface area essential for cell attachment is overcome by the presence of larger pores that lead to a better cell infiltration and migration into scaffold. Finally, larger pores are also essential for scaffold vascularization and to provide boundaries for the tissue regrowth [73]. In our study, we found that the peculiar morphology of PEUUF scaffolds with high porosity and multi-scale pore size allowed cell recruitment and scaffold colonization. Indeed, when the PEUUF scaffold was laid over a fibroblast layer, cells were able to attach themselves to the biomaterial and migrate and proliferate into the scaffold. After 30 days of migration, it was evidenced that these fibroblasts had spread over the pore walls in an elongated pattern.

\subsection{Ability of PRP-PEUUF Scaffolds to Promote Cell Recruitment and Proliferation}

PRP contains more than 300 biologically-active molecules, including diffusible factors and macromolecules, regulating cell metabolisms or cell-extracellular matrix (ECM) interactions [8]. Therefore, PRP has been largely used to supplement cell culture media, or to stimulate and accelerate tissue regeneration $[9,77,78]$. Although neither a standard operating procedure nor any quality procedure are available, the efficiency of PRP in the field of tissue engineering has been shown despite 
of its heterogeneity. Promising results have been obtained with PRP-containing scaffolds, because PRP derivatives are capable of promoting cell adhesion, migration, proliferation, differentiation and of stimulating tissue growth [79-84]. The incorporation of PRP into scaffolds is an advantageous approach because it represents a simple, efficient and cost-effective method, allowing the immobilization of a number of highly concentrated bioactive factors, creating an optimized micro-environment and impacting on tissue regeneration. In most studies, PRP was immobilized within scaffolds in a dry state, or was directly used in hydrogel form [79-81,83-85].

In our study, PRP was immobilized in wetted scaffolds in the form of a fibrillar gel onto the pore walls and across pores, serving as a biological support for cell adhesion and scaffold colonization in a 3D spatial distribution layout. With the appropriate PRP concentration, the open porosity of the scaffold was maintained that is of high importance for the migration of cells, the diffusion of nutrients, and the overall bio-integration and tissue regeneration, when the scaffold is implanted in vivo. It was found that both PEUUF and PRP-PEUUF scaffolds allowed cell recruitment and subsequent migration. Nevertheless, PRP-PEUUF scaffolds exhibited an increase of the initial cell infiltration by comparison with PEUUF scaffolds. In addition, while the proliferation seemed to stop between 20 and 35 days in PEUUF scaffolds, continuous migration and proliferation were found into PRP-PEUUF ones. The immobilization of PRP enhanced the cell initial recruitment, migration, and proliferation, probably due to chemotactic factors and the adhesive protein-fibronectin contained in PRP [82]. Moreover while cells remained flattened on the pore walls of PEUUF scaffolds, layer of cells bridging pores were found within PRP-PEUUF ones. PRP-PEUUF scaffolds also exhibited an increase of the collagenous matrix deposit. In addition, we found that non-functionalized scaffolds synthesized in an absence of fucoidan and impregnated with PRP did not lead to the 3D arrangement of cells inside the scaffold porous structure and to the increase of collagen deposit, attesting the importance of the synergic effect of the presence of platelet-derived growth factors with LMW fucoidan to improve cell response $[8,86]$. Indeed, it was reported that sulfated glycosaminoglycans are capable of promoting a collagenous matrix, thus making and structuring matrix macromolecules, which are key events in soft-tissue repair [28,86-90]. Overall, the improved cell infiltration and more rapid colonization into PRP-PEUUF scaffolds, associated with a peculiar 3D cell distribution inside the scaffold and a higher collagen synthesis, suggested that PRP-PEUUF scaffolds might lead to some improved performance in vivo through potentiated regenerative properties. Finally, it has to be pointed out that the clinical PRP formulation used in our study was prepared from pools of platelets in order to achieve a maximal standardization and avoid the response heterogeneity from the PRP batch. The PRP adsorption was also realized after the scaffold sterilization, in order to avoid the loss and inactivation of growth factors due to high temperature. Therefore, this method of bio-activation is a simple and reproducible technique that can be easily reproduced by surgeons at the surgical block.

\section{Conclusions}

Our work brought out an easy and versatile way of developing bio-activated elastomeric poly(ester-urea-urethane) scaffolds. By combining the LMW fucoidan functionalization with PRP immobilization, we developed a scaffold that was capable of recruiting cells, acting as a 3D support for colonization, as well as mimicking the extracellular matrix to provide biological cues leading to cell response promotion. The scaffolds possessed properties suitable for soft-tissue regeneration, and will be investigated further in future with respect to in vivo animal testing to assess the interactions between PRP-PEUUF scaffolds and tissues, and therefore the in vivo performance.

Author Contributions: Conceptualization, G.R., K.S. and S.C.; methodology, G.R. and S.C.; investigation, G.R., C.L., S.R. and S.C.; resources, K.S., J.-J.L. and D.L.; writing-review \& editing, G.R.

Funding: There were no external sources of funding for the research described in this manuscript.

Acknowledgments: The authors thank the Ministère de l'Enseignement Supérieur, de la Recherche et de l'Innovation for the MENRT scholarship granted to Credson Langueh. The authors would also like to thank Gabriela Radu Bostan, Dyhia Kersani and Sandra Njikeu for their technical assistance in our laboratory, Muriel 
Nivet from Centre de Transfusion Sanguine des Armées “Jean Julliard" for her kind assistance in supplying PRP formulations, Solabia Group for providing low-molecular-weight fucoidan, as well as Laboratory MSSMAT UMR CNRS 8579 from Central Supelec for the use of the Alicona InfiniteFocus microscope.

Conflicts of Interest: The authors declare no conflict of interest.

\section{References}

1. Sachlos, E.; Czernuszka, J.T. Making Tissue Engineering Scaffolds Work. Review: The application of solid freeform fabrication technology to the production of tissue engineering scaffolds. Eur. Cell. Mater. 2003, 5, 29-40. [CrossRef] [PubMed]

2. Ko, I.K.; Lee, S.J.; Atala, A.; Yoo, J.J. In situ tissue regeneration through host stem cell recruitment. Exp. Mol. Med. 2013, 45, e57. [CrossRef] [PubMed]

3. Chen, W.L.K.; Simmons, C.A. Lessons from (patho)physiological tissue stiffness and their implications for drug screening, drug delivery and regenerative medicine. Adv. Drug Deliv. Rev. 2011, 63, 269-276. [CrossRef] [PubMed]

4. Bettinger, C.J. Biodegradable elastomers for tissue engineering and cell-biomaterial interactions. Macromol. Biosci. 2011, 11, 467-482. [CrossRef] [PubMed]

5. Cooper, S.L.; Guan, J. (Eds.) Advances in Polyurethane Biomaterials; Woodhead Publishing: Cambridge, $\mathrm{UK}, 2016$.

6. Qiu, Z.-Y.; Chen, C.; Wang, X.-M.; Lee, I.-S. Advances in the surface modification techniques of bone-related implants for last 10 years. Regen. Biomater. 2014, 1, 67-79. [CrossRef] [PubMed]

7. Chen, F.-M.; Zhang, M.; Wu, Z.-F. Toward delivery of multiple growth factors in tissue engineering. Biomaterials 2010, 31, 6279-6308. [CrossRef]

8. Pavlovic, V.; Ciric, M.; Jovanovic, V.; Stojanovic, P. Platelet rich plasma: a short overview of certain bioactive components. Open Med. 2016, 11, 242-247. [CrossRef] [PubMed]

9. Lang, S.; Loibl, M.; Herrmann, M. Platelet-rich plasma in tissue engineering: Hype and hope. Eur. Surg. Res. 2018, 59, 265-275. [CrossRef] [PubMed]

10. Reddy, S.H.R.; Reddy, R.; Babu, N.C.; Ashok, G.N. Stem-cell therapy and platelet-rich plasma in regenerative medicines: A review on pros and cons of the technologies. J. Oral Maxillofac. Pathol. JOMFP 2018, 22, 367-374. [CrossRef]

11. Shimojo, A.A.M.; Perez, A.G.M.; Galdames, S.E.M.; Brissac, I.C.d.S.; Santana, M.H.A. Performance of PRP associated with porous chitosan as a composite scaffold for regenerative medicine. ScientificWorldJournal 2015, 2015, 396131. [CrossRef]

12. Sánchez, M.; Delgado, D.; Garate, A.; Sánchez, P.; Oraa, J.; Bilbao, A.M.; Guadilla, J.; Aizpurua, B.; Fiz, N.; Azofra, J.; et al. PRP injections in orthopaedic surgery: Why, when and how to use PRP dynamic liquid scaffold injections in orthopaedic surgery. In Plasma Medicine-Concepts and Clinical Applications; Tutar, Y., Tutar, L., Eds.; IntechOpen: London, UK, 2018; pp. 37-58.

13. Doucet, C.; Ernou, I.; Zhang, Y.; Llense, J.-R.; Begot, L.; Holy, X.; Lataillade, J.-J. Platelet lysates promote mesenchymal stem cell expansion: A safety substitute for animal serum in cell-based therapy applications. J. Cell. Physiol. 2005, 205, 228-236. [CrossRef] [PubMed]

14. Leotot, J.; Coquelin, L.; Bodivit, G.; Bierling, P.; Hernigou, P.; Rouard, H.; Chevallier, N. Platelet lysate coating on scaffolds directly and indirectly enhances cell migration, improving bone and blood vessel formation. Acta Biomater. 2013, 9, 6630-6640. [CrossRef] [PubMed]

15. Cho, E.B.; Park, G.S.; Park, S.S.; Jang, Y.J.; Kim, K.H.; Kim, K.J.; Park, E.J. Effect of platelet-rich plasma on proliferation and migration in human dermal fibroblasts. J. Cosmet. Dermatol. 2018. [CrossRef] [PubMed]

16. Ruggiu, A.; Ulivi, V.; Sanguineti, F.; Cancedda, R.; Descalzi, F. The effect of Platelet Lysate on osteoblast proliferation associated with a transient increase of the inflammatory response in bone regeneration. Biomaterials 2013, 34, 9318-9330. [CrossRef] [PubMed]

17. Vinod, E.; Vinod Francis, D.; Manickam Amirtham, S.; Sathishkumar, S.; Boopalan, P.R.J.V.C. Allogeneic platelet rich plasma serves as a scaffold for articular cartilage derived chondroprogenitors. Tissue Cell 2019, 56, 107-113. [CrossRef] [PubMed] 
18. Miroshnichenko, S.; Timofeeva, V.; Permyakova, E.; Ershov, S.; Kiryukhantsev-Korneev, P.; Dvořaková, E.; Shtansky, D.; Zajíčková, L.; Solovieva, A.; Manakhov, A. Plasma-coated polycaprolactone nanofibers with covalently bonded platelet-rich plasma enhance adhesion and growth of human fibroblasts. Nanomaterials 2019, 9, 637. [CrossRef] [PubMed]

19. Fang, D.; Jin, P.; Huang, Q.; Yang, Y.; Zhao, J.; Zheng, L. Platelet-rich plasma promotes the regeneration of cartilage engineered by mesenchymal stem cells and collagen hydrogel via the TGF- $\beta$ /SMAD signaling pathway. J. Cell. Physiol. 2019. [CrossRef]

20. Wang, Z.; Wang, Z.; Lu, W.W.; Zhen, W.; Yang, D.; Peng, S. Novel biomaterial strategies for controlled growth factor delivery for biomedical applications. NPG Asia Mater. 2017, 9, e435. [CrossRef]

21. Hortensius, R.A.; Harley, B.A.C. The use of bioinspired alterations in the glycosaminoglycan content of collagen-GAG scaffolds to regulate cell activity. Biomaterials 2013, 34, 7645-7652. [CrossRef]

22. Paluck, S.J.; Nguyen, T.H.; Maynard, H.D. Heparin-mimicking polymers: Synthesis and biological applications. Biomacromolecules 2016, 17, 3417-3440. [CrossRef]

23. Purnama, A.; Aid-Launais, R.; Haddad, O.; Maire, M.; Mantovani, D.; Letourneur, D.; Hlawaty, H.; Le Visage, C. Fucoidan in a 3D scaffold interacts with vascular endothelial growth factor and promotes neovascularization in mice. Drug Deliv. Transl. Res. 2015, 5, 187-197. [CrossRef] [PubMed]

24. Rujitanaroj, P.-O.; Aid-Launais, R.; Chew, S.Y.; Le Visage, C. Polysaccharide electrospun fibers with sulfated poly(fucose) promote endothelial cell migration and VEGF-mediated angiogenesis. Biomater. Sci. 2014, 2, 843-852. [CrossRef]

25. Luyt, C.-E.; Meddahi-Pellé, A.; Ho-Tin-Noe, B.; Colliec-Jouault, S.; Guezennec, J.; Louedec, L.; Prats, H.; Jacob, M.-P.; Osborne-Pellegrin, M.; Letourneur, D.; et al. Low-molecular-weight fucoidan promotes therapeutic revascularization in a rat model of critical hindlimb ischemia. J. Pharmacol. Exp. Ther. 2003, 305, 24-30. [CrossRef] [PubMed]

26. Lake, A.C.; Vassy, R.; Di Benedetto, M.; Lavigne, D.; Le Visage, C.; Perret, G.Y.; Letourneur, D. Low Molecular Weight Fucoidan Increases VEGF 165 -induced Endothelial Cell Migration by Enhancing VEGF 165 Binding to VEGFR-2 and NRP1. J. Biol. Chem. 2006, 281, 37844-37852. [CrossRef] [PubMed]

27. Senni, K.; Gueniche, F.; Foucault-Bertaud, A.; Igondjo-Tchen, S.; Fioretti, F.; Colliec-Jouault, S.; Durand, P.; Guezennec, J.; Godeau, G.; Letourneur, D. Fucoidan a sulfated polysaccharide from brown algae is a potent modulator of connective tissue proteolysis. Arch. Biochem. Biophys. 2006, 445, 56-64. [CrossRef] [PubMed]

28. Senni, K.; Pereira, J.; Gueniche, F.; Delbarre-Ladrat, C.; Sinquin, C.; Ratiskol, J.; Godeau, G.; Fischer, A.-M.; Helley, D.; Colliec-Jouault, S. Marine polysaccharides: A source of bioactive molecules for cell therapy and tissue engineering. Mar. Drugs 2011, 9, 1664-1681. [CrossRef] [PubMed]

29. Nakamura, S.; Nambu, M.; Ishizuka, T.; Hattori, H.; Kanatani, Y.; Takase, B.; Kishimoto, S.; Amano, Y.; Aoki, H.; Kiyosawa, T.; et al. Effect of controlled release of fibroblast growth factor-2 from chitosan/fucoidan micro complex-hydrogel onin vitro andin vivo vascularization. J. Biomed. Mater. Res. A 2008, 85A, 619-627. [CrossRef] [PubMed]

30. Marinval, N.; Morenc, M.; Labour, M.N.; Samotus, A.; Mzyk, A.; Ollivier, V.; Maire, M.; Jesse, K.; Bassand, K.; Niemiec-Cyganek, A.; et al. Fucoidan/VEGF-based surface modification of decellularized pulmonary heart valve improves the antithrombotic and re-endothelialization potential of bioprostheses. Biomaterials 2018, 172, 14-29. [CrossRef] [PubMed]

31. Chollet, L.; Saboural, P.; Chauvierre, C.; Villemin, J.-N.; Letourneur, D.; Chaubet, F. Fucoidans in nanomedicine. Mar. Drugs 2016, 14, 145. [CrossRef] [PubMed]

32. Fitton, J.H. Therapies from fucoidan; Multifunctional marine polymers. Mar. Drugs 2011, 9, 1731-1760. [CrossRef]

33. Changotade, S.; Radu Bostan, G.; Consalus, A.; Poirier, F.; Peltzer, J.; Lataillade, J.-J.; Lutomski, D.; Rohman, G. Preliminary in Vitro assessment of stem cell compatibility with cross-linked poly( $\varepsilon$-caprolactone urethane) scaffolds designed through high internal phase emulsions. Stem Cells Int. 2015, 2015, 283796. [CrossRef] [PubMed]

34. Rohman, G.; Changotade, S.; Frasca, S.; Ramtani, S.; Consalus, A.; Langueh, C.; Collombet, J.-M.; Lutomski, D. In vitro and in vivo proves of concept for the use of a chemically cross-linked poly(ester-urethane-urea) scaffold as an easy handling elastomeric biomaterial for bone regeneration. Regen. Biomater. 2019. [CrossRef] 
35. Rohman, G.; Ramtani, S.; Changotade, S.; Langueh, C.; Lutomski, D.; Roussigné, Y.; Tétard, F.; Caupin, F.; Djemia, P. Characterization of elastomeric scaffolds developed for tissue engineering applications by compression and nanoindentation tests, $\mu$-Raman and $\mu$-Brillouin spectroscopies. Biomed. Opt. Express 2019, 10, 1649-1659. [CrossRef] [PubMed]

36. Rohman, G.; Baker, S.C.; Southgate, J.; Cameron, N.R. Heparin functionalisation of porous PLGA scaffolds for controlled, biologically relevant delivery of growth factors for soft tissue engineering. J. Mater. Chem. 2009, 19, 9265-9273. [CrossRef]

37. Junqueira, L.C.U.; Bignolas, G.; Brentani, R.R. Picrosirius staining plus polarization microscopy, a specific method for collagen detection in tissue sections. Histochem. J. 1979, 11, 447-455. [CrossRef]

38. Martoja, R.; Martoja-Pierson, M. Initiation Aux Techniques de L'histologie Animale; Masson \& Cie: Paris, France, 1967.

39. Ben-Dor, G.; Mazor, G.; Cederbaum, G.; Igra, O. Stress-strain relations for elastomeric foams in uni-, bi- and tri-axial compression modes. Arch. Appl. Mech. 1996, 66, 409-418. [CrossRef]

40. Wang, C.-Y.; Chen, Y.-C. Extraction and characterization of fucoidan from six brown macroalgae. J. Mar. Sci. Technol. 2016, 24, 319-328. [CrossRef]

41. Barbosa, A.; Costa Lima, S.; Reis, S. Application of $\mathrm{pH}$-responsive fucoidan/chitosan nanoparticles to improve oral quercetin delivery. Molecules 2019, 24,346. [CrossRef]

42. Rani, V.; Shakila, R.J.; Jawahar, P.; Srinivasan, A. Influence of Species, Geographic Location, Seasonal Variation and Extraction Method on the Fucoidan Yield of the Brown Seaweeds of Gulf of Mannar, India. Indian J. Pharm. Sci. 2017, 79, 65-79. [CrossRef]

43. Huang, C.-Y.; Kuo, C.-H.; Chen, P.-W. Compressional-puffing pretreatment enhances neuroprotective effects of fucoidans from the brown seaweed sargassum hemiphyllum on 6-hydroxydopamine-induced apoptosis in SH-SY5Y cells. Molecules 2017, 23, 78. [CrossRef]

44. Mahomed, A. Ageing processes of biomedical polymers in the body. In Durability and Reliability of Medical Polymers; Jenkins, M., Stamboulis, A., Eds.; Woodhead Publishing Limited: Cambridge, UK, 2012; pp. 164-182.

45. Sabbatini, S.; Conti, C.; Orilisi, G.; Giorgini, E. Infrared spectroscopy as a new tool for studying single living cells: Is there a niche? Biomed. Spectrosc. Imaging 2017, 6, 85-99. [CrossRef]

46. Muylaert, D.E.; Fledderus, J.O.; Bouten, C.V.; Dankers, P.Y.; Verhaar, M.C. Combining tissue repair and tissue engineering; bioactivating implantable cell-free vascular scaffolds. Heart 2014, 100, 1825-1830. [CrossRef] [PubMed]

47. Aibibu, D.; Hild, M.; Wöltje, M.; Cherif, C. Textile cell-free scaffolds for in situ tissue engineering applications. J. Mater. Sci. Mater. Med. 2016, 27, 63. [CrossRef] [PubMed]

48. Wang, W.; Deng, D.; Wang, B.; Zhou, G.; Zhang, W.; Cao, Y.; Zhang, P.; Liu, W. Comparison of autologous, allogeneic, and cell-free scaffold approaches for engineered tendon repair in a rabbit mode-A pilot study. Tissue Eng. Part A 2017, 23, 750-761. [CrossRef] [PubMed]

49. Kaewprag, J.; Ruangsawasdi, N. Regenerative endodontics: Cell-based versus cell-free approach. Mahidol Dent. J. 2018, 38, 313-320.

50. Janoušková, O. Synthetic polymer scaffolds for soft tissue engineering. Physiol. Res. 2018, 67, S335-S348. [PubMed]

51. Zhu, Z.; Zhang, Q.; Chen, L.; Ren, S.; Xu, P.; Tang, Y.; Luo, D. Higher specificity of the activity of low molecular weight fucoidan for thrombin-induced platelet aggregation. Thromb. Res. 2010, 125, 419-426. [CrossRef]

52. Ale, M.T.; Mikkelsen, J.D.; Meyer, A.S. Important determinants for fucoidan bioactivity: A critical review of structure-function relations and extraction methods for fucose-containing sulfated polysaccharides from brown seaweeds. Mar. Drugs 2011, 9, 2106-2130. [CrossRef]

53. Park, S.-B.; Chun, K.-R.; Kim, J.-K.; Suk, K.; Jung, Y.-M.; Lee, W.-H. The differential effect of high and low molecular weight fucoidans on the severity of collagen-induced arthritis in mice. Phytother. Res. 2010, 24, 1384-1391. [CrossRef]

54. Ustyuzhanina, N.E.; Bilan, M.I.; Ushakova, N.A.; Usov, A.I.; Kiselevskiy, M.V.; Nifantiev, N.E. Fucoidans: Pro- or antiangiogenic agents? Glycobiology 2014, 24, 1265-1274. [CrossRef]

55. Song, Y.S.; Li, H.; Balcos, M.C.; Yun, H.-Y.; Baek, K.J.; Kwon, N.S.; Choi, H.-R.; Park, K.-C.; Kim, D.-S. Fucoidan promotes the reconstruction of skin equivalents. Korean J. Physiol. Pharmacol. 2014, 18, 327-331. [CrossRef] [PubMed] 
56. O'Leary, R.; Rerek, M.; Wood, E.J. Fucoidan modulates the effect of transforming growth factor (TGF)- $\beta 1$ on fibroblast proliferation and wound repopulation in in vitro models of dermal wound repair. Biol. Pharm. Bull. 2004, 27, 266-270. [CrossRef] [PubMed]

57. Lee, J.S.; Jin, G.H.; Yeo, M.G.; Jang, C.H.; Lee, H.; Kim, G.H. Fabrication of electrospun biocomposites comprising polycaprolactone/fucoidan for tissue regeneration. Carbohydr. Polym. 2012, 90, 181-188. [CrossRef] [PubMed]

58. Rossi, F.; van Griensven, M. Polymer functionalization as a powerful tool to improve scaffold performances. Tissue Eng. Part A 2014, 20, 2043-2051. [CrossRef] [PubMed]

59. Pajovich, H.T.; Banerjee, I.A. Biomineralization of fucoidan-peptide blends and their potential applications in bone tissue regeneration. J. Funct. Biomater. 2017, 8, 41. [CrossRef] [PubMed]

60. Perumal, R.K.; Perumal, S.; Thangam, R.; Gopinath, A.; Ramadass, S.K.; Madhan, B.; Sivasubramanian, S. Collagen-fucoidan blend film with the potential to induce fibroblast proliferation for regenerative applications. Int. J. Biol. Macromol. 2018, 106, 1032-1040. [CrossRef] [PubMed]

61. Kizling, J.; Kronberg, B.; Eriksson, J.C. On the formation and stability of high internal phase O/W emulsions. Adv. Colloid Interface Sci. 2006, 123-126, 295-302. [CrossRef]

62. Nikiforidis, C.V.; Scholten, E. High internal phase emulsion gels (HIPE-gels) created through assembly of natural oil bodies. Food Hydrocoll. 2015, 43, 283-289. [CrossRef]

63. Rohman, G.; Huot, S.; Vilas-Boas, M.; Radu-Bostan, G.; Castner, D.G.; Migonney, V. The grafting of a thin layer of poly(sodium styrene sulfonate) onto poly( $\varepsilon$-caprolactone) surface can enhance fibroblast behavior. J. Mater. Sci. Mater. Med. 2015, 26, 206. [CrossRef]

64. Dai, Z.; Ronholm, J.; Tian, Y.; Sethi, B.; Cao, X. Sterilization techniques for biodegradable scaffolds in tissue engineering applications. J. Tissue Eng. 2016, 7, 1-13. [CrossRef]

65. Webb, A.R.; Yang, J.; Ameer, G.A. Biodegradable polyester elastomers in tissue engineering. Expert Opin. Biol. Ther. 2004, 4, 801-812. [CrossRef] [PubMed]

66. Chang, H.-I.; Wang, Y. Cell responses to surface and architecture of tissue engineering scaffolds. In Regenerative Medicine and Tissue Engineering_Cells and Biomaterials; Eberli, D., Ed.; IntechOpen: London, UK, 2011; pp. 569-588.

67. Lotfi, M.; Nejib, M.; Naceur, M. Cell adhesion to biomaterials: Concept of biocompatibility. In Advances in Biomaterials Science and Biomedical Applications; Pignatello, R., Ed.; IntechOpen: London, UK, 2013.

68. Freyman, T.M.; Yannas, I.V.; Gibson, L.J. Cellular materials as porous scaffolds for tissue engineering. Prog. Mater. Sci. 2001, 46, 273-282. [CrossRef]

69. Murphy, C.M.; O’Brien, F.J.; Little, D.G.; Schindeler, A. Cell-scaffold interactions in the bone tissue engineering triad. Eur. Cell. Mater. 2013, 26, 120-132. [CrossRef] [PubMed]

70. Harley, B.A.C.; Kim, H.-D.; Zaman, M.H.; Yannas, I.V.; Lauffenburger, D.A.; Gibson, L.J. Microarchitecture of three-dimensional scaffolds influences cell migration behavior via junction interactions. Biophys. J. 2008, 95, 4013-4024. [CrossRef] [PubMed]

71. Harley, B.A.; Freyman, T.M.; Wong, M.Q.; Gibson, L.J. A New technique for calculating individual dermal fibroblast contractile forces generated within collagen-GAG scaffolds. Biophys. J. 2007, 93, 2911-2922. [CrossRef]

72. Caliari, S.R.; Harley, B.A.C. The effect of anisotropic collagen-GAG scaffolds and growth factor supplementation on tendon cell recruitment, alignment, and metabolic activity. Biomaterials 2011, 32, 5330-5340. [CrossRef]

73. Murphy, C.M.; Haugh, M.G.; O’Brien, F.J. The effect of mean pore size on cell attachment, proliferation and migration in collagen-glycosaminoglycan scaffolds for bone tissue engineering. Biomaterials 2010, 31, 461-466. [CrossRef]

74. Yang, J.; Shi, G.; Bei, J.; Wang, S.; Cao, Y.; Shang, Q.; Yang, G.; Wang, W. Fabrication and surface modification of macroporous poly(L-lactic acid) and poly(L-lactic-co-glycolic acid) (70/30) cell scaffolds for human skin fibroblast cell culture. J. Biomed. Mater. Res. 2002, 62, 438-446. [CrossRef]

75. Ashworth, J.C.; Mehr, M.; Buxton, P.G.; Best, S.M.; Cameron, R.E. Towards cellular sieving: Exploring the limits of scaffold accessibility for cell type specific invasion. Adv. Biosyst. 2018, 2, 1700257. [CrossRef]

76. Ashworth, J.C.; Mehr, M.; Buxton, P.G.; Best, S.M.; Cameron, R.E. Optimising collagen scaffold architecture for enhanced periodontal ligament fibroblast migration. J. Mater. Sci. Mater. Med. 2018, 29, 166. [CrossRef] 
77. Rožman, P.; Bolta, Z. Use of platelet growth factors in treating wounds and soft-tissue injurie. Acta Dermatovenerol. Alp. Panon. Adriat. 2007, 16, 156-165.

78. Jacobson, M.; Fufa, D.; Abreu, E.L.; Kevy, S.; Murray, M.M. Platelets, but not erythrocytes, significantly affect cytokine release and scaffold contraction in a provisional scaffold model. Wound Repair Regen. 2008, 16, 370-378. [CrossRef] [PubMed]

79. Hafeman, A.E.; Li, B.; Yoshii, T.; Zienkiewicz, K.; Davidson, J.M.; Guelcher, S.A. Injectable biodegradable polyurethane scaffolds with release of platelet-derived growth factor for tissue repair and regeneration. Pharm. Res. 2008, 25, 2387-2399. [CrossRef] [PubMed]

80. Sell, S.A.; Wolfe, P.S.; Ericksen, J.J.; Simpson, D.G.; Bowlin, G.L. Incorporating platelet-rich plasma into electrospun scaffolds for tissue engineering applications. Tissue Eng. Part A 2011, 17, 2723-2737. [CrossRef] [PubMed]

81. Díaz-Gómez, L.; Alvarez-Lorenzo, C.; Concheiro, A.; Silva, M.; Dominguez, F.; Sheikh, F.A.; Cantu, T.; Desai, R.; Garcia, V.L.; Macossay, J. Biodegradable electrospun nanofibers coated with platelet-rich plasma for cell adhesion and proliferation. Mater. Sci. Eng. C Mater. Biol. Appl. 2014, 40, 180-188. [CrossRef] [PubMed]

82. Solovieva, A.; Miroshnichenko, S.; Kovalskii, A.; Permyakova, E.; Popov, Z.; Dvořáková, E.; Kiryukhantsev-Korneev, P.; Obrosov, A.; Polčak, J.; Zajičková, L.; et al. Immobilization of platelet-rich plasma onto $\mathrm{COOH}$ plasma-coated PCL nanofibers boost viability and proliferation of human mesenchymal stem cells. Polymers 2017, 9, 736. [CrossRef]

83. Mazzucco, L.; Balbo, V.; Cattana, E.; Guaschino, R.; Borzini, P. Not every PRP-gel is born equal Evaluation of growth factor availability for tissues through four PRP-gel preparations: Fibrinet ${ }^{\circledR}$, RegenPRP-Kit ${ }^{\circledR}$, Plateltex ${ }^{\circledR}$ and one manual procedure. Vox Sang. 2009, 97, 110-118. [CrossRef] [PubMed]

84. Sadeghi-Ataabadi, M.; Mostafavi-pour, Z.; Vojdani, Z.; Sani, M.; Latifi, M.; Talaei-Khozani, T. Fabrication and characterization of platelet-rich plasma scaffolds for tissue engineering applications. Mater. Sci. Eng. C Mater. Biol. Appl. 2017, 71, 372-380. [CrossRef] [PubMed]

85. Rožman, P.; Semenič, P.; Smrke, D.M. The role of platelet gel in regenerative medicine. In Advances in Regenerative Medicine; Wislet-Gendebien, S., Ed.; IntechOpen: London, UK, 2011; pp. 319-348.

86. Senni, K.; Pellat, B.; Gogly, B.; Blondin, C.; Letourneur, D.; Jozefonvicz, J.; Sinquin, C.; Colliec-Jouault, S.; Durand, P. Use of Fucane for Regulating the Reconstruction of Connective Tissue. U.S. Patent No. 6,559,131, 6 May 2003.

87. Logeart, D.; Letourneur, D.; Jozefonvicz, J.; Kern, P. Collagen synthesis by vascular smooth muscle cells in the presence of antiproliferative polysaccharides. J. Biomed. Mater. Res. 1996, 30, 501-508. [CrossRef]

88. Senni, K.; Borchiellini, C.; Duchesnay, A.; Pellat, B.; Letourneur, D.; Kern, P. Antiproliferative polysaccharides modulate distribution and phenotypic expression of collagens by gingival fibroblasts. J. Biomed. Mater. Res. 1998, 40, 164-169. [CrossRef]

89. Igondjo Tchen Changotade, S.; Korb, G.; Bassil, J.; Barroukh, B.; Willig, C.; Colliec-Jouault, S.; Durand, P.; Godeau, G.; Senni, K. Potential effects of a low-molecular-weight fucoidan extracted from brown algae on bone biomaterial osteoconductive properties. J. Biomed. Mater. Res. A 2008, 87A, 666-675. [CrossRef] [PubMed]

90. Senni, K.; Gueniche, F.; Changotade, S.; Septier, D.; Sinquin, C.; Ratiskol, J.; Lutomski, D.; Godeau, G.; Guezennec, J.; Colliec-Jouault, S. Unusual gycosaminoglycans from a deep sea hydrothermal bacterium improve fibrillar collagen structuring and fibroblast activities in engineered connective tissues. Mar. Drugs 2013, 11, 1351-1369. [CrossRef] [PubMed]

(C) 2019 by the authors. Licensee MDPI, Basel, Switzerland. This article is an open access article distributed under the terms and conditions of the Creative Commons Attribution (CC BY) license (http://creativecommons.org/licenses/by/4.0/). 